\title{
Advances in drug development for hepatocellular carcinoma: clinical trials and potential therapeutic targets
}

\author{
Xiang-Yuan Luo ${ }^{1,2}$, Kong-Ming $\mathrm{Wu}^{3,4}$ and Xing-Xing $\mathrm{He}^{1,2^{*}}$ (D)
}

\begin{abstract}
Although hepatocellular carcinoma (HCC) is one of the deadliest health burdens worldwide, few drugs are available for its clinical treatment. However, in recent years, major breakthroughs have been made in the development of new drugs due to intensive fundamental research and numerous clinical trials in HCC. Traditional systemic therapy schemes and emerging immunotherapy strategies have both advanced. Between 2017 and 2020, the United States Food and Drug Administration (FDA) approved a variety of drugs for the treatment of HCC, including multikinase inhibitors (regorafenib, lenvatinib, cabozantinib, and ramucirumab), immune checkpoint inhibitors (nivolumab and pembrolizumab), and bevacizumab combined with atezolizumab. Currently, there are more than 1000 ongoing clinical trials involving HCC, which represents a vibrant atmosphere in the HCC drug research and development field. Additionally, traditional Chinese medicine approaches are being gradually optimized. This review summarizes FDA-approved agents for HCC, elucidates promising agents evaluated in clinical phase I/I/III trials and identifies emerging targets for HCC treatment. In addition, we introduce the development of HCC drugs in China. Finally, we discuss potential problems in HCC drug therapy and possible future solutions and indicate future directions for the development of drugs for HCC treatment.
\end{abstract}

Keywords: Liver cancer, Treatment, Molecular mechanism, Traditional Chinese medicine, Immunotherapy

\section{Background}

Hepatocellular carcinoma (HCC) is one of the deadliest health burdens worldwide [1]. Most patients with HCC have dismal outcomes because of insufficient early diagnosis and few available treatment options for patients with advanced-stage HCC [2].

In recent years, with the rapid advancement of molecular biology techniques, such as highthroughput sequencing, microarrays, and various

\footnotetext{
* Correspondence: xxhe@tjh.tjmu.edu.cn

'Institute of Liver and Gastrointestinal Diseases, Tongji Hospital, Tongji Medical College, Huazhong University of Science and Technology, Wuhan 430030, China

${ }^{2}$ Hubei Key Laboratory of Hepato-Pancreato-Biliary Diseases, Tongji Hospital, Tongji Medical College, Huazhong University of Science and Technology, Wuhan 430030, China

Full list of author information is available at the end of the article
}

omics techniques, a more global and thorough understanding of the molecular mechanisms of HCC has been acquired. In particular, the role of epigenetics has been well established and is as important as genetics. The use of integrated multiomics analyses has recently led to outstanding advancements in the indepth understanding of the molecular hallmarks involved in the initiation and progression of HCC and helped to comprehensively map key signaling pathways and aberrant molecular events in HCC [3-11] (Fig. 1). These valuable technological advances have brought several significant breakthroughs, led to many clinical trials (Table 1), and promoted the approval of multiple drugs by the United States Food and Drug Administration (FDA) (Fig. 2). In 2017-2019, the FDA approved the multikinase inhibitors regorafenib, 


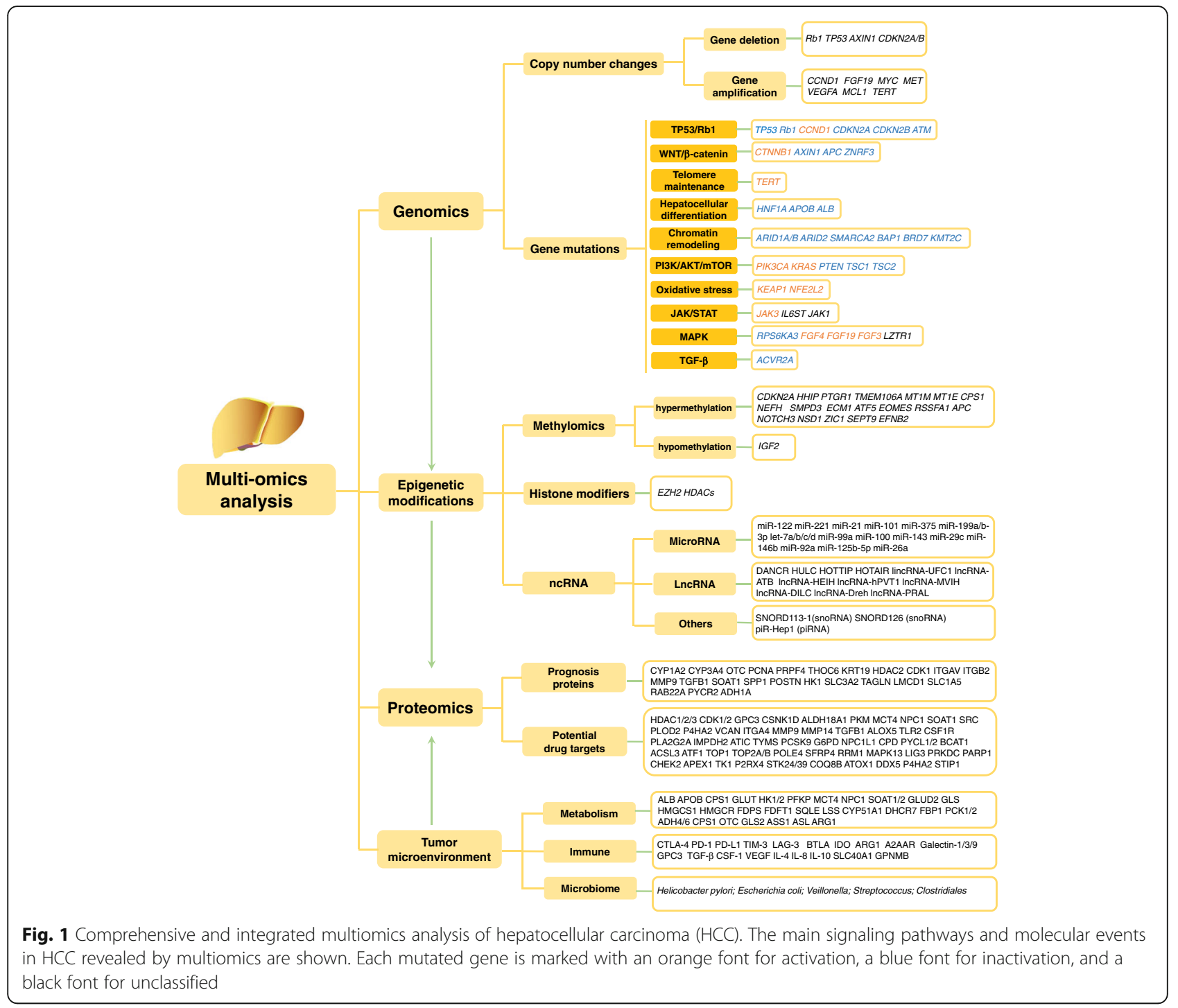

lenvatinib, cabozantinib, and ramucirumab for $\mathrm{HCC}$ [25-28]. Notably, the approval of lenvatinib and of bevacizumab in combination with atezolizumab as two first-line treatment strategies have substantially changed treatment options for HCC as, previously, sorafenib was the only feasible first-line treatment for advanced HCC. Meanwhile, immune checkpoint blockade (ICB) therapy that targets programmed cell death-1 and its ligand (PD-1/PD-L1) and cytotoxic Tlymphocyte-associated protein 4 (CTLA-4) has been remarkably successful for the treatment of melanoma and non-small cell lung cancer, which paved the way for immunotherapy for HCC [29, 30]. In 2017-2018, the FDA accelerated the approval of the anti-PD-1 antibodies nivolumab and pembrolizumab as secondline treatments for patients with $\mathrm{HCC}[31,32]$. In addition, the technology for extracting active substances from therapies used in traditional Chinese medicine (TCM) has progressed dramatically, facilitating the exploration of the pharmacological mechanisms underlying TCM. All these developments show optimistic prospects for HCC drug treatment.

In this review, we summarize the FDA-approved agents for HCC, clarify the promising agents being evaluated in phase I/II/III trials as reported at ClinicalTrials.gov (supported by the US National Library of Medicine) from the molecular mechanism perspective, and outline the emerging targets for HCC treatment. We introduce the development of HCC drugs in China. In addition, we discuss the potential problems in HCC drug treatment discovered in recent years and present some feasible solutions. Finally, we indicate the possible future directions of drug development for HCC treatment. 


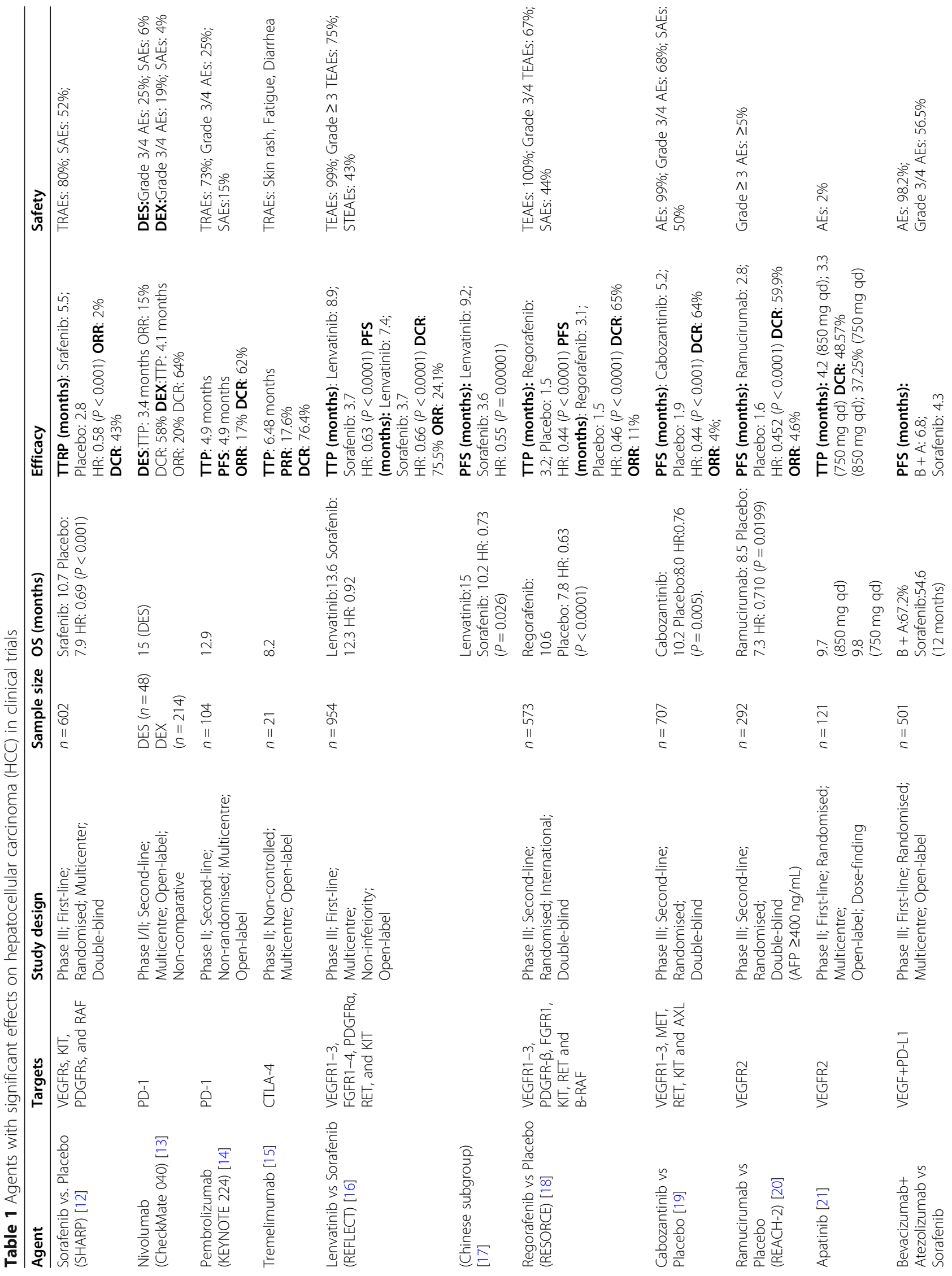




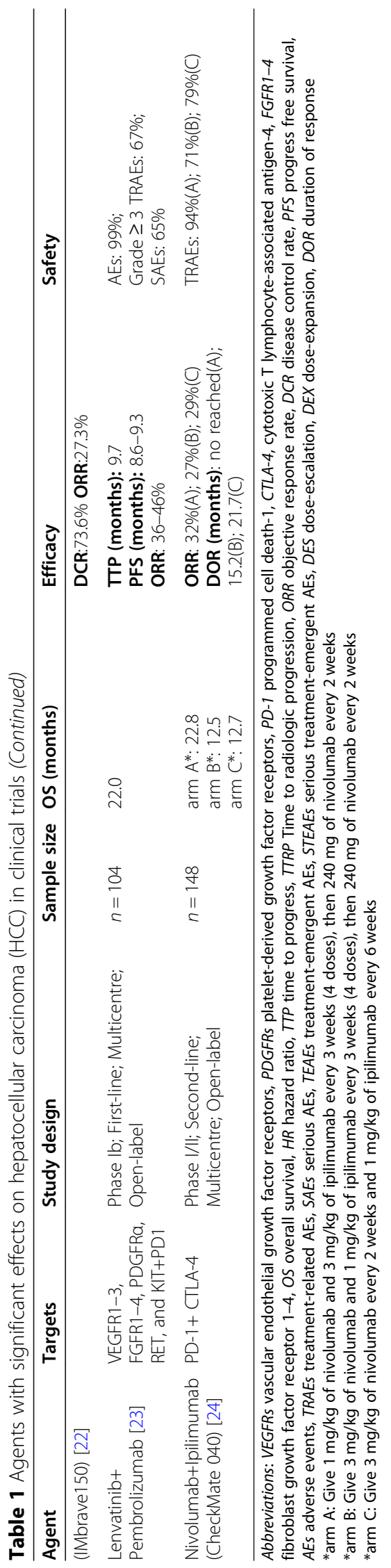




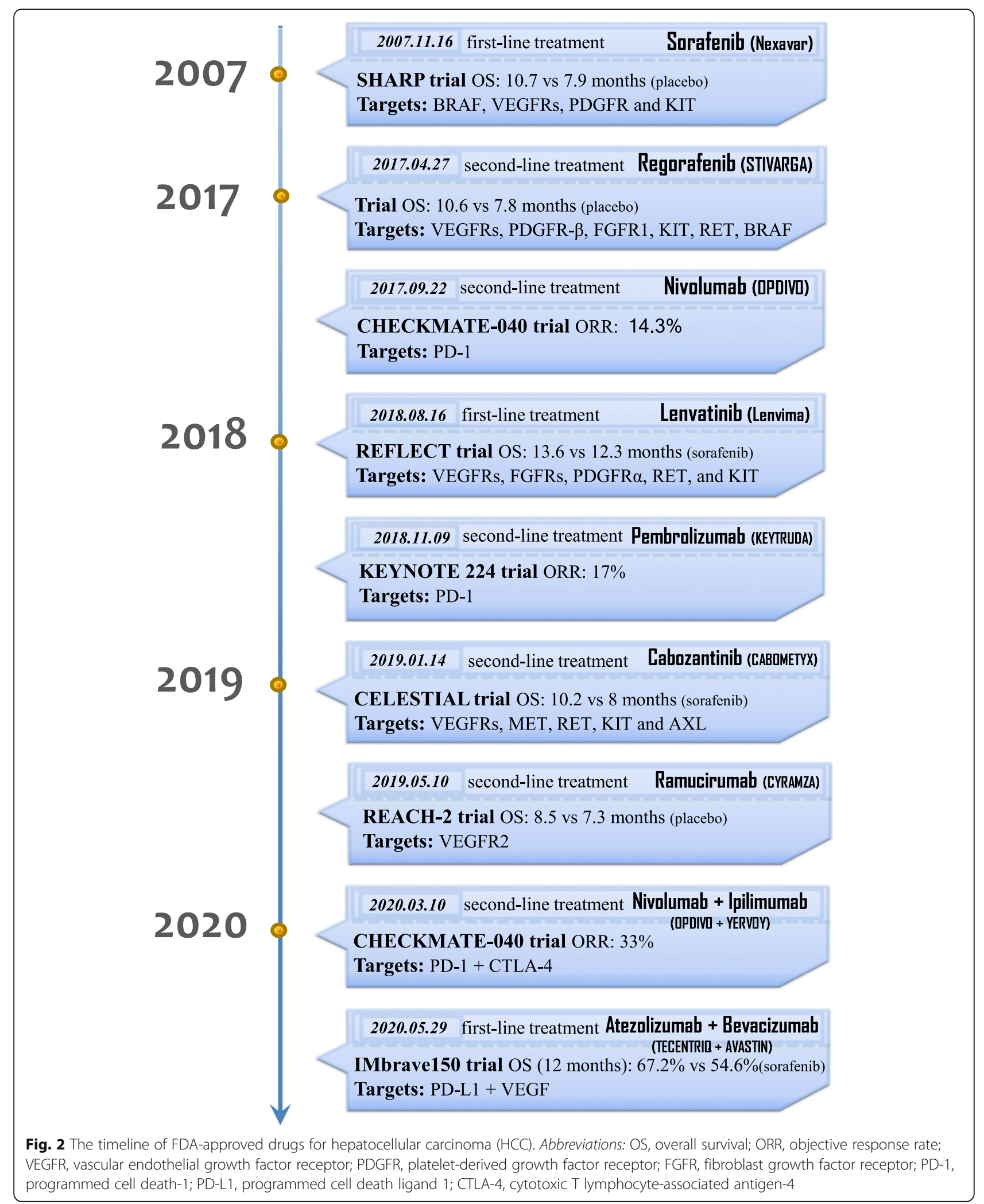




\section{Agents approved for HCC First-line treatment Sorafenib}

Sorafenib is a multikinase inhibitor that blocks the activity of RAF-1, BRAF, VEGFRs, PDGFR, and KIT receptors involved in cell proliferation and angiogenesis [33, 34]. It has been the standard first-line treatment for patients with advanced HCC since the FDA approved sorafenib for HCC in 2007 [35]. The Sorafenib Hepatocellular Carcinoma Assessment Randomized Protocol (SHARP) trial and the sorafenib Asia-Pacific (AP) trial have previously demonstrated the benefit of sorafenib compared with a placebo for patients with advanced HCC without systemic treatment $[12,36]$. Herein, the median overall survival (OS) of the sorafenib group was prolonged by approximately 2-3 months, and the secondary endpoints were also significantly favorable in both trials $[12,36]$. However, the partial response rate (PRR) of the sorafenib group was relatively low (2\% in SHARP and $3.3 \%$ in AP), and the participants did not achieve a complete response in either trial $[12,36]$. In addition, the clinical application of sorafenib is limited by tumor heterogeneity, tumor escape, and the lack of predictive biomarkers for response to the treatment $[37,38]$. Regarding the safety profile, the most frequent grade $3 / 4$ sorafenib-related adverse events (AEs) are hand-foot skin reaction (HFSR), fatigue, and diarrhea [12, 36] (Table 1).

Because of patients' inadequate response to sorafenib, its management is critical to improve the efficacy, especially to manage AEs and select patients most likely to respond [39]. HFSR (the most common $\mathrm{AE}$ ) is the most noteworthy challenge. Although various methods are used to prevent or minimize the effect of HFSR, including urea-based creams and the dose-reduction of sorafenib, clinical monitoring is necessary for the first 2 months during sorafenib therapy owing to the current high incidence of HFSR $[39,40]$. Importantly, some AEs, such as skin-related AEs, may serve as potential biomarkers to predict sorafenib efficacy due to the significant correlation between AEs and survival [41, 42]. For the management of patient selection, the aim is to identify the patients most likely to respond to sorafenib treatment. Bruix et al. [43] thoroughly analyzed the results of two phase III trials, which showed that all patient subgroups treated with sorafenib had a survival benefit. Nevertheless, for patients with $\mathrm{HCV}$, liverconfined disease (without EHS), or a lower neutrophil: lymphocyte ratio, sorafenib has a greater benefit [43].

\section{Lenvatinib}

Lenvatinib, which targets VEGFR 1-3, FGFR 1-4, PDGF $R \alpha, R E T$, and $K I T$, is the first-line systemic therapy drug for advanced HCC [17]. In 2018, the results of a randomized phase III trial (REFLECT) demonstrated that lenvatinib was noninferior to sorafenib in terms of OS [16]. The median OS was 13.6 months for lenvatinib compared to 12.3 months for sorafenib [16]. And all secondary endpoints (progression-free survival $\langle\mathrm{PFS}\rangle$, time to progression $\langle\mathrm{TTP}\rangle$, and objective response rate $<\mathrm{ORR}>$ ) exhibited significant improvement with lenvatinib compared with sorafenib [16] (Table 1). The common AEs included hypertension (42\%), diarrhea (39\%), decreased appetite (34\%), and decreased weight (31\%) [16]. In addition, since hepatic arterial infusion chemotherapy (HAIC) is mainly applied for localized advanced HCC and has shown more beneficial long-term outcomes in Japan [44], the efficacy and safety of lenvatinib combined with HAIC for patients with advanced HCC is being evaluated in a randomized controlled phase III trial (NCT03775395).

\section{Bevacizumab plus Atezolizumab}

In recent years, immunotherapy, especially the ICB strategy, has been frequently explored for tumor treatment and has shown substantial clinical efficacy. ICB is a way to directly protect against immune checkpoint proteins. Once these proteins bind to specific ligands in the tumor environment, they suppress immune cell immune function, thereby blocking the antitumor immune response [45]. PD-L1 is one of the ligands of the immune checkpoint protein $\mathrm{PD}-1$.

In 2020, the FDA approved the combination strategy of bevacizumab (anti-VEGF antibody) plus atezolizumab (anti-PD-L1 antibody) as a first-line treatment for unresectable HCC based on the results of the IMbrave150 trial (NCT03434379) [22, 46]. In this phase III trial, the efficacy of bevacizumab combined with atezolizumab was compared with sorafenib in 501 patients with HCC without prior systemic therapy [22]. The combination treatment resulted in a substantially better outcome than sorafenib monotherapy, increasing the OS by $12.6 \%$ at 12 months and markedly prolonging the PFS by 2.5 months [22] (Table 1). In addition, there was no significant difference in the incidence of AEs between the combination treatment group and sorafenib group, and no AEs beyond the safety profile of the single drug and the effects of the underlying disease were found [22]. Therefore, bevacizumab in combination with atezolizumab treatment was determined to be relatively safe for patients with HCC.

\section{Second-line treatment Regorafenib}

In April 2017, regorafenib became the first agent approved by the FDA as a second-line therapy for patients with advanced HCC who progressed after sorafenib treatment [25]. Regorafenib is a multikinase inhibitor that mainly targets angiogenic factors, including VEGF 
R1-3, PDGFR- $\beta$, FGFR1, KIT, RET, and BRAF. Regorafenib possesses even more robust inhibitory activity than sorafenib [47]. Based on the results of a randomized, placebo-controlled phase III trial in 2017 (NCT01774344), regorafenib was more potent than the placebo with a mortality reduction of $37 \%$ (median survival of 10.6 months for regorafenib versus 7.8 months for placebo) [18, 48] (Table 1). Of note, this trial only enrolled patients with Child-Pugh A liver function to decrease the impact of deteriorative liver function on the trial outcomes [18]. Furthermore, biomarker-related studies regarding this treatment approach have still not progressed.

\section{Cabozantinib}

Cabozantinib is a multitarget tyrosine kinase inhibitor (TKI) that mainly blocks VEGFR2 and MET, although it has effects on VEGFR1/3, RET, KIT, and $A X L$ [49]. Its approval was based on a randomized, placebo-controlled phase III trial (CELESTIAL) that showed that the median survival was prolonged by 2.2 months in the cabozantinib group (NCT01908426) [19] (Table 1). In particular, among patients who previously received sorafenib alone, the median survival in the cabozantinib group was 11.3 months [12, 19]. This finding indicated the advantage of cabozantinib as a second-line treatment for improving patient survival compared with sorafenib alone (median survival of 10.7 months) [12, 19]. Additionally, cabozantinib has the potential to partially resolve the problem of MET-induced sorafenib resistance, which has been shown in previously reported studies $[50,51]$. Furthermore, there is evidence that MET, HGF, GAS6, VEGF-A, ANG2, and IL-8 serve as biomarkers to predict the prognosis of patients treated with cabozantinib [52].

\section{Ramucirumab}

Ramucirumab is a recombinant IgG1 monoclonal antibody (mAb) that specifically targets VEGFR2. In 2015, Zhu et al. [53] completed a randomized phase III trial evaluating ramucirumab as second-line therapy for patients with advanced HCC (REACH). Unfortunately, they failed to obtain the anticipated outcome [53]. Interestingly, in contrast to the fact that a high level of $\alpha$ fetoprotein (AFP) suggests a poor prognosis, they found that an elevated baseline level of AFP $(\geq 400 \mathrm{ng} / \mathrm{mL})$ contributed to prolonged survival with ramucirumab treatment [53]. Hence, a subsequent REACH-2 trial reevaluated ramucirumab with a new inclusion criterion of $\mathrm{AFP} \geq 400 \mathrm{ng} / \mathrm{mL}$ (NCT02435433). According to a report from the American Society of Clinical Oncology (ASCO) annual meeting in June 2018, the efficacy of ramucirumab was improved (median OS of 8.5 months for ramucirumab group versus 7.3 months for placebo group), and the safety profile was manageable (Table 1) [20]. This first biomarker-based trial with favorable results in HCC led to the FDA approval of ramucirumab as a second-line treatment for patients with HCC patients AFP level was $\geq 400 \mathrm{ng} / \mathrm{mL}[28,54]$.

\section{Immune checkpoint inhibitors (ICls)}

Nivolumab PD-1 is one of the essential immune checkpoints and is highly expressed in exhausted $\mathrm{T}$ cells, $\mathrm{B}$ cells, and myeloid cells $[55,56]$. In 2017, based on positive results from an open-label, noncomparative, phase I/II dose escalation and expansion trial (CheckMate 040) [13] (NCT01658878), the anti-PD-1 mAb nivolumab resulted in a 15-month OS. Regardless of the therapeutic line for advanced HCC, the ORR with nivolumab was $15-20 \%$, much better than the $2 \%$ ORR with sorafenib $[13,35]$ (Table 1). It is worth noting that there is clear evidence that $82 \%$ of nonintervention patients have an ORR of $23 \%$ and OS of 9 months, which provides a basis for the application of nivolumab as a first-line treatment for patients with advanced HCC [13]. In 2019, the European Society for Medical Oncology (ESMO) reported clinical trial (CheckMate 459) data that showed that nivolumab paralleled the efficacy of sorafenib as a first-line treatment for advanced HCC, though there was no statistically significant difference in OS (16.4 months median OS for nivolumab versus 14.7 months for sorafenib) [57]. In addition, nivolumab was reported to be safer than sorafenib (22\% AEs verse 46\% AEs) [57]. Nevertheless, similar to sorafenib, there is no reliable response biomarker for nivolumab. Moreover, it is unclear which groups of patients with advanced HCC benefit the most from nivolumab treatment. All of the above are issues that require more attention in future research.

Pembrolizumab Pembrolizumab is another PD-1 mAb that has been granted accelerated approval by the FDA for HCC treatment. In 2018, the results of a single-arm phase II trial (KEYNOTE 224) showed that pembrolizumab elicited an encouraging response and had manageable toxicity in HCC patients [14] (Table 1). Specifically, the ORR of patients treated with pembrolizumab reached 17\%, with one patient achieving complete response and 17 achieving partial responses [14]. The median OS was 12.9 months, and $54 \%$ of patients were alive after 12 months [14]. However, this trial had some limitations, namely the lack of a randomized control arm, the absence of an evaluation of the progression of patients treated with sorafenib, and inadequate analysis between biomarkers and pembrolizumab treatment response [14]. Subsequently, two large randomized controlled phase III trials, KEYNOTE-240 (NCT02702401) and KEYNOTE-394 (NCT03062358), were conducted to 
further test pembrolizumab treatment for HCC. According to the latest report of the KEYNOTE-240 clinical trial, pembrolizumab failed to meet the statistically prespecified OS and PFS [58]. Nevertheless, the OS and PFS in the pembrolizumab group were improved compared to the placebo group (13.9-month OS and 3.0-month PFS with the pembrolizumab; 10.6-month OS and 2.8month PFS with the placebo) [58]. The ORR was $18.3 \%$ in the pembrolizumab group, significantly higher than the $4.4 \%$ ORR in the placebo group [58]. In summary, this was the first phase III trial to reveal the efficacy of checkpoint inhibitors for the treatment of HCC and provides evidence to support pembrolizumab's accelerated approval.

Nivolumab plus ipilimumab The combination of ICIs is a novel and effective treatment strategy for HCC. In 2020, the FDA accelerated the approval of nivolumab plus ipilimumab (anti-CTLA-4 antibody) as a secondline treatment for HCC based on the results of the CheckMate 040 clinical trial [24]. The results of this trial indicated that the ORR of the arm A dosage regimen (nivolumab $1 \mathrm{mg} / \mathrm{kg}$ and ipilimumab $3 \mathrm{mg} / \mathrm{kg}$ every 3 weeks, then nivolumab $240 \mathrm{mg}$ every 2 weeks) reached $32 \%$, which was higher than that of the other two dosage regimens [24] (Table 1). However, given the limitations of this trial, a randomized controlled trial involving a larger patient sample with stratification will be needed in the future. This combination regimen is currently being evaluated as a first-line treatment for HCC in a phase III trial (NCT04039607). In addition, the CheckMate 040 trial results showed the following clinically meaningful outcomes: the ORR of nivolumab, ipilimumab, and cabozantinib combination treatment for HCC was $26 \%$, the disease control rate (DCR) was $83 \%$, and the median PFS was 6.8 months [59]. The median OS has not yet been reached [59].

\section{Promising agents in clinical trials for HCC}

In previous decades, antiangiogenic therapy has been the core strategy against HCC, since angiogenesis is an indispensable condition for the survival of malignant tumors. With the continuous advancement of science and technology, substantial progress has been made in the study of the genome and epigenome of tumors and has provided a profound and comprehensive understanding of the hepatocarcinogenesis mechanism, thereby promoting the development of more potential HCC treatment drugs involving multiple mechanisms. (shown in Fig. 3). Currently, there are more than 1000 ongoing clinical trials related to $\mathrm{HCC}$, which represents a vibrant atmosphere in the area of drug research for HCC.

\section{Agents in phase III trials}

Based on the excellent antitumor effects of ICIs in clinical trials for HCC, researchers have applied therapeutic strategies combining these ICIs with other agents to improve their efficacy (Table 2), many of which have obtained promising results in early-stage clinical trials and are currently being tested in phase III trials. In addition, there are other promising agents for HCC treatment currently being evaluated in phase III trials.

\section{ICls combined with angiogenesis inhibitors}

Previous studies have shown that antiangiogenesis and immunotherapy have a synergistic antitumor effect, jointly inducing tumor immune stimulation and vascular remodeling [60-62]. Furthermore, the relatively different AEs that arise with angiogenesis inhibitor and ICI treatments may facilitate their use as a combination therapy [63]. Specifically, the combination of lenvatinib and PD$1 \mathrm{mAb}$ enhances antitumor capacity by minimizing monocytes and macrophages (antitumor immunity inhibition) to increase the activation of CD8+ T cells [64]. Early-stage clinical trials have shown promising outcomes with lenvatinib combined with pembrolizumab as the first-line treatment for unresectable HCC [23]. In this combination therapy group, the ORR was $36-46 \%$, PFS was 8.6-9.3 months, OS was 22 months, and the toxicity was manageable (NCT03006926) [23] (Table 1). This combination therapy was granted breakthrough therapy designation by the FDA in 2020 for use as a first-line treatment [23]. Currently, a phase III trial evaluating lenvatinib plus pembrolizumab as the firstline treatment of unresectable $\mathrm{HCC}$ is underway (NCT03713593). In addition, Xu et al. [65] conducted a phase I/II trial of apatinib (anti-VEGFR2) plus SHR1210 (anti-PD-1 mAb) for HCC and gastric cancer in 2018. In this trial, the ORR was reached $53.8 \%$ in the group that received the combination treatment with 250 mg apatinib [65]. Of note, the DCR was $93.8 \%$, and 6and 9-month PFS reached 51.3 and $41.0 \%$, respectively, which were significantly higher than those of the nivolumab-alone group [13, 65] (Table 1). This combination was evaluated as a first-line treatment in a phase III trial for advanced HCC (NCT03764293). Similarly, many other ICIs combined with angiogenesis inhibitors are being actively tested in phase III trials for HCC. For example, CS1003 (anti-PD-1 mAb) plus lenvatinib (NCT04194775) and durvalumab (anti-PD-L1 mAb) plus bevacizumab (NCT03847428) (other combination therapies are summarized in Table 2).

\section{ICls combined with other ICls}

The combination of ICIs with other ICIs has also achieved satisfactory outcomes in previous clinical trials [66]. In 2020, the ASCO published the results of a phase 


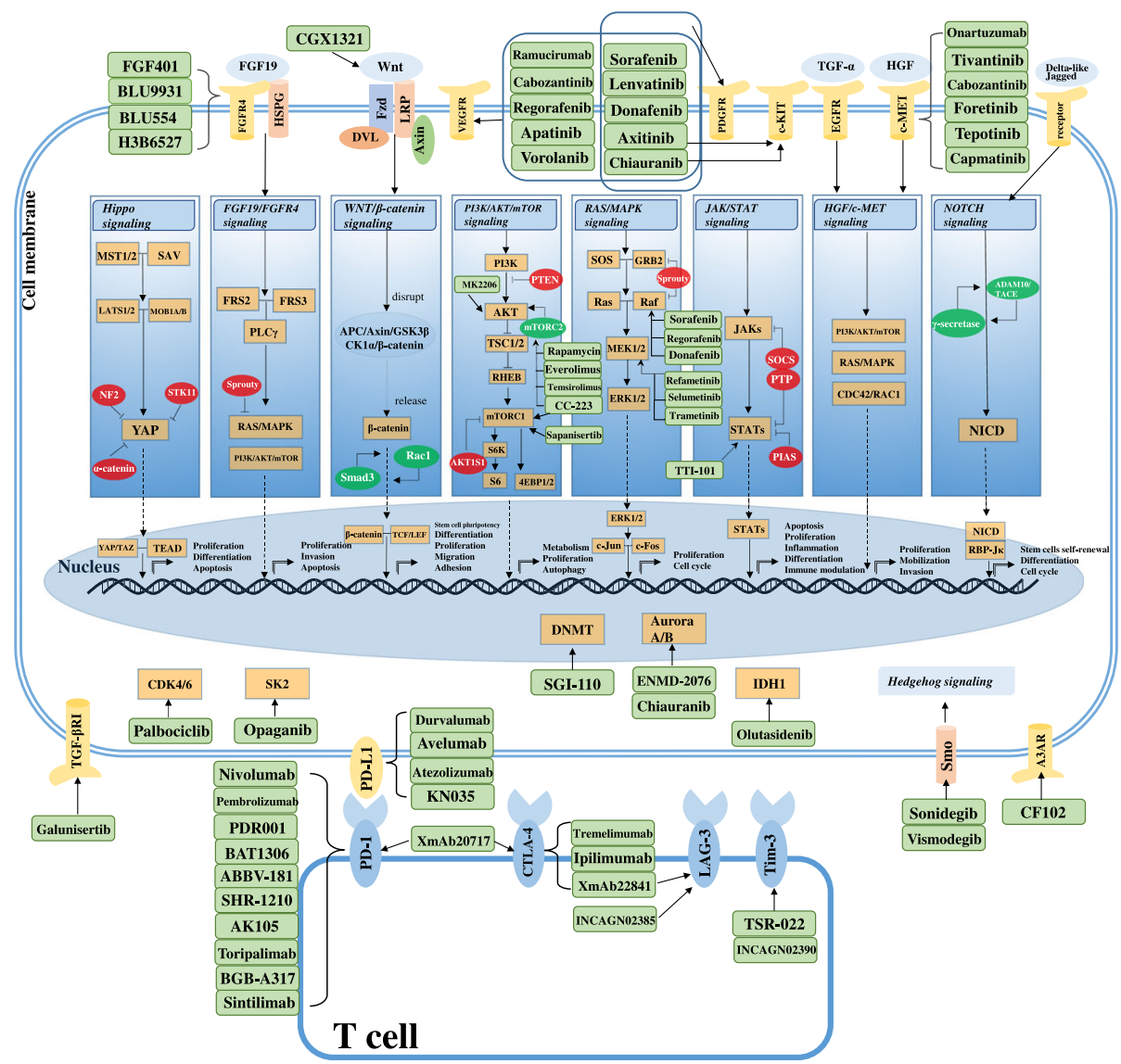

Fig. 3 The main signaling pathways and molecular targets of targeted therapy for hepatocellular carcinoma (HCC). We summarize several crucial and well-established signaling pathways that drive HCC initiation and progression, as well as the core functional molecules and their partial regulators in these signaling cascades, and then list their targeted agents currently in clinical studies. Abbreviations: MST1/2, macrophage stimulating 1 and 2; SAV, salvador family WW domain containing protein; LATS1/2, large tumor suppressor kinases 1 and 2; MOB1A/B, MOB kinase activators $1 A$ and $B$; YAP, yes-associated protein 1; NF2, neurofibromin 2; STK11, serine/threonine kinase 11; TEAD, TEA domain transcription factor; WWTR1/TAZ, WW domain containing transcription regulator 1; FGF19, fibroblast growth factor 19; FGFR4, fibroblast growth factor receptor 4; HSPG, heparin sulphate proteoglycans; FRS2/3, fibroblast growth factor receptor substrate 2 and 3; PLC $\gamma$, phospholipase C gamma 1; Fzd, frizzled; LRP, low-density lipoprotein receptor-related protein; DVL, dishevelled; APC, adenomatous polyposis coli; GSK3 $\beta$, glycogen synthase kinase $3 \beta$; CK1a, casein kinase 1a; Smad3, mothers against decapentaplegic homolog 3; Rac1, Rac family small GTPase 1; TCF/LEF, T-cell factor/lymphoid enhancer factor; PI3K, phosphoinositide 3-kinase; PTEN, phosphatase and tensin homologue; TSC1/2, tuberous sclerosis 1/2; mTORC1/2, mammalian target of rapamycin complex 1/2; RHEB, RAS homologue enriched in brain; S6K, S6 kinase; AKT1S1, Akt1 substrate 1; 4EBP1/2, eukaryotic translation-initiation factor 4E-binding protein 1/2; MAPK, mitogen-activated protein kinase; SOS, SOS Ras/Rac guanine nucleotide exchange factor; GRB2, growth factor receptor bound-2; MEK1/2, mitogen-activated protein kinase kinase 1/2; ERK1/2, extracellular signalregulated kinase 1/2; JAKs, janus kinases; STATs, signal transducers and activators of transcription; SOCS, suppressors of cytokine signaling; PTP, protein tyrosine phosphatase; PIAS, protein inhibitors of activated STAT; EGFR, epidermal growth factor receptor; TGF-a, transforming growth factor a; HGF, hepatocyte growth factor; CDC42, cell division cycle 42; ADAM10/TACE, tumor necrosis factor-converting enzyme; NICD, notch intracellular domain; RBP-JK, DNA-binding recombination signal-binding protein JK; VEGFR, vascular endothelial growth factor receptor; PDGFR, platelet-derived growth factor receptor; TGF- $\beta$ R1, transforming growth factor beta receptor 1; CDK4/6, cyclin dependent kinase 4/6; SK2, sphingosine kinase 2; DNMT, DNA methyltransferase; IDH1, isocitrate dehydrogenase (NADP (+)) 1; Smo, smoothened, frizzled class receptor; A3AR, adenosine A3 receptor; PD-1, programmed cell death-1; PD-L1, programmed cell death ligand 1; CTLA-4, cytotoxic T lymphocyte-associated antigen-4; LAG-3, lymphocyte activating 3; Tim-3, T-Cell immunoglobulin and mucin domain-containing molecule 3

II trial involving durvalumab (anti-PD-L1 mAb) plus tremelimumab (anti-CTLA-4 mAb) treatment in a secondline setting for advanced HCC (NCT02519348). The high-dose combination treatment group (300 mg tremelimumab, T300) had an OS of 18.7 months, an ORR of $22.7 \%$, and acceptable safety, while the other two monotherapy groups and the low-dose combination group
(75 mg tremelimumab, T75) had poor survival and a limited response to the treatment [67]. T300 plus durvalumab is currently being evaluated as a first-line treatment for HCC in a phase III trial (NCT03298451). ICI combination treatments, including IBI310 (anti-CTLA-4 $\mathrm{mAb}$ ) plus sintilimab injection (PD-1 inhibitor) are currently being evaluated in phase III trials 
Table 2 Combination treatment of hepatocellular carcinoma (HCC) in clinical trials

\begin{tabular}{|c|c|c|c|c|c|c|}
\hline Drug & Targets & $\begin{array}{l}\text { Stage and } \\
\text { conditions }\end{array}$ & Phase & $\begin{array}{l}\text { Primary } \\
\text { endpoint(s) }\end{array}$ & $\begin{array}{l}\text { ClinicalTrials.gov } \\
\text { Identifier }\end{array}$ & $\begin{array}{l}\text { Study } \\
\text { start }\end{array}$ \\
\hline \multicolumn{7}{|c|}{ Immunotherapy plus Anti-angiogenesis } \\
\hline $\begin{array}{l}\text { Atezolizumab plus Lenvatinib } \\
\text { or Sorafenib }\end{array}$ & $\begin{array}{l}\text { PD-L1 + VEGFRs, } \\
\text { FGFRs, } \\
\text { PDGFR a, RET, KIT } \\
\text { and RAF }\end{array}$ & $\begin{array}{l}\text { Advanced; } \\
\text { Second-line }\end{array}$ & III & OS & NCT04770896 & 2021 \\
\hline SHR-1210 plus Apatinib & PD-1 + VEGFR-2 & $\begin{array}{l}\text { Advanced; } \\
\text { First-line }\end{array}$ & III & OS/PFS & NCT03764293 & 2019 \\
\hline CS1003 plus Lenvatinib & $\begin{array}{l}\text { PD-1 + VEGFRs, FGFRs, } \\
\text { PDGFR a, RET and KIT }\end{array}$ & $\begin{array}{l}\text { Advanced; } \\
\text { First-line }\end{array}$ & III & OS/PFS & NCT04194775 & 2019 \\
\hline Durvalumab plus Bevacizumab & PD-L1 + VEGFA & $\begin{array}{l}\text { High risk of } \\
\text { recurrence; } \\
\text { Second-line }\end{array}$ & III & RFS & NCT03847428 & 2019 \\
\hline Atezolizumab plus Bevacizumab & PD-L1 + VEGFA & $\begin{array}{l}\text { Locally advanced or } \\
\text { metastatic; First-line }\end{array}$ & III & OS/PFS & NCT03434379 & 2018 \\
\hline Atezolizumab plus Cabozantinib & $\begin{array}{l}\text { PD-L1 + VEGFR, MET, } \\
\text { RET, KIT and AXL }\end{array}$ & $\begin{array}{l}\text { Advanced; } \\
\text { First-line }\end{array}$ & III & OS/PFS & NCT03755791 & 2018 \\
\hline Pembrolizumab plus Lenvatinib & $\begin{array}{l}\text { PD-1 + VEGFRs, FGFRs, } \\
\text { PDGFR a, RET and KIT }\end{array}$ & $\begin{array}{l}\text { Advanced; } \\
\text { First-line }\end{array}$ & III & OS/PFS & NCT03713593 & 2018 \\
\hline Nivolumab plus Sorafenib & $\begin{array}{l}\text { PD-1 + VEGFRs, KIT, } \\
\text { PDGFRs, and RAF }\end{array}$ & $\begin{array}{l}\text { Locally Advanced or } \\
\text { Metastatic; First-line }\end{array}$ & $\|$ & MTD/ORR & NCT03439891 & 2018 \\
\hline Avelumab plus Regorafenib & $\begin{array}{l}\text { PD-L1 + VEGFR1-3, } \\
\text { PDGFR- } \beta \text {, FGFR1, KIT, } \\
\text { RET and B-RAF }\end{array}$ & $\begin{array}{l}\text { Advanced or } \\
\text { metastatic }\end{array}$ & $|/| \mid$ & $\mathrm{RP} 2 \mathrm{D} / \mathrm{ORR}$ & NCT03475953 & 2018 \\
\hline Nivolumab plus Cabozantinib & $\begin{array}{l}\text { PD-1 + VEGFR, MET, } \\
\text { RET, KIT and AXL }\end{array}$ & $\begin{array}{l}\text { Locally Advanced; } \\
\text { Neoadjuvant }\end{array}$ & । & AEs & NCT03299946 & 2018 \\
\hline Nivolumab plus Bevacizumab & PD-1 + VEGFA & $\begin{array}{l}\text { Advanced or } \\
\text { Metastatic }\end{array}$ & । & $\begin{array}{l}\text { AEs/MTD or } \\
\text { RP2D }\end{array}$ & NCT03382886 & 2018 \\
\hline Durvalumab plus Cabozantinib & $\begin{array}{l}\text { PD-L1 + VEGFR, MET, } \\
\text { RET, KIT and AXL }\end{array}$ & $\begin{array}{l}\text { Advanced; } \\
\text { Second-line }\end{array}$ & । & MTD & NCT03539822 & 2018 \\
\hline Nivolumab plus Vorolanib & PD-1 + VEGFR, PDGFR & / & I & $\mathrm{RP} 2 \mathrm{D}$ & NCT03511222 & 2018 \\
\hline PDR001 plus Sorafenib & $\begin{array}{l}\text { PD-1 + VEGFRs, KIT, } \\
\text { PDGFRs, and RAF }\end{array}$ & $\begin{array}{l}\text { Advanced; } \\
\text { First-line }\end{array}$ & 1 & AEs & NCT02988440 & 2017 \\
\hline Pembrolizumab plus Regorafenib & $\begin{array}{l}\text { PD-1 + VEGFR1-3, } \\
\text { PDGFR- } \beta \text {, FGFR1, KIT, } \\
\text { RET and B-RAF }\end{array}$ & $\begin{array}{l}\text { Advanced; } \\
\text { First-line }\end{array}$ & 1 & AEs/DLTs & NCT03347292 & 2018 \\
\hline Durvalumab plus Ramucirumab & PD-L1 + VEGFR2 & $\begin{array}{l}\text { Advanced or } \\
\text { metastatic }\end{array}$ & । & DLTS & NCT02572687 & 2016 \\
\hline \multicolumn{7}{|l|}{ Immunotherapy plus other agents } \\
\hline IBI310 plus Sintilimab & CTLA-4 + PD-1 & $\begin{array}{l}\text { Advanced; } \\
\text { First-line }\end{array}$ & III & OS/ORR & NCT04720716 & 2021 \\
\hline Nivolumab plus Ipilimumab & PD-1 + CTLA-4 & $\begin{array}{l}\text { Advanced; } \\
\text { First-line }\end{array}$ & III & OS & NCT04039607 & 2019 \\
\hline Durvalumab plus Tremelimumab & PD-L1 + CTLA-4 & $\begin{array}{l}\text { Advanced; } \\
\text { First-line }\end{array}$ & III & OS & NCT03298451 & 2017 \\
\hline TSR-042 plus TSR-022 & PD-1 + TIM-3 & $\begin{array}{l}\text { Locally advanced or } \\
\text { metastatic }\end{array}$ & $\|$ & ORR & NCT03680508 & 2018 \\
\hline Pembrolizumab plus Bavituximab & PD-1 + PS & $\begin{array}{l}\text { Advanced; } \\
\text { First-line }\end{array}$ & $\|$ & ORR & NCT03519997 & 2018 \\
\hline Nivolumab plus BMS-986205 & PD-1 + IDO1 & $\begin{array}{l}\text { Advanced; } \\
\text { First-line }\end{array}$ & $|/| \mid$ & AEs/ORR & NCT03695250 & 2018 \\
\hline Pembrolizumab plus Epacadostat & PD-1 + IDO1 & / & $|/| \mid$ & DLTs/ORR & NCT02178722 & 2014 \\
\hline Pembrolizumab plus INCAGN01876 & PD-1 + GITR+IDO1 & Advanced & $|/| \mid$ & AEs/ORR & NCT03277352 & 2017 \\
\hline
\end{tabular}


Table 2 Combination treatment of hepatocellular carcinoma (HCC) in clinical trials (Continued)

\begin{tabular}{|c|c|c|c|c|c|c|}
\hline Drug & Targets & $\begin{array}{l}\text { Stage and } \\
\text { conditions }\end{array}$ & Phase & $\begin{array}{l}\text { Primary } \\
\text { endpoint(s) }\end{array}$ & $\begin{array}{l}\text { ClinicalTrials.gov } \\
\text { Identifier }\end{array}$ & $\begin{array}{l}\text { Study } \\
\text { start }\end{array}$ \\
\hline Nivolumab plus Galunisertib & $P D-1+T \beta R I$ & $\begin{array}{l}\text { Advanced; } \\
\text { Recurrent }\end{array}$ & $|/| \mid$ & MTD & NCT02423343 & 2015 \\
\hline Nivolumab plus Avadomide & PD-1 + CRBN & Unresectable & $|/| \mid$ & DLT/AEs/ORR & NCT02859324 & 2016 \\
\hline Pembrolizumab plus VSV-IFN $\beta$-NIS & PD-1 + Oncolytic virus & Refractory & I & ORR/AEs & NCT03647163 & 2019 \\
\hline Durvalumab plus Guadecitabine & PD-L1 + DNMT & $\begin{array}{l}\text { Advanced; } \\
\text { Metastatic }\end{array}$ & I & AEs/ORR & NCT03257761 & 2018 \\
\hline Pembrolizumab plus XL888 & PD-1 + Hsp90 & $\begin{array}{l}\text { Advanced; } \\
\text { Metastatic }\end{array}$ & । & $\mathrm{RP} 2 \mathrm{D}$ & NCT03095781 & 2017 \\
\hline Pembrolizumab plus Vaccine & $\begin{array}{l}\text { PD-1 + Modified } \\
\text { Vaccinia Virus Ankara } \\
\text { Vaccine Expressing p53 }\end{array}$ & $\begin{array}{l}\text { Unresectable; } \\
\text { Second-line }\end{array}$ & 1 & Tolerability & NCT02432963 & 2015 \\
\hline PDR001 plus NIS793 & PD-1 + TGF- $\beta$ & Advanced & 1 & DLTs/AEs & NCT02947165 & 2017 \\
\hline Nivolumab plus SF1126 & PD-1 + PI3K & Advanced & I & DLT & NCT03059147 & 2017 \\
\hline \multicolumn{7}{|l|}{ Other combination } \\
\hline Apatinib plus Capecitabine & $\begin{array}{l}\text { VEGFR-2 + DNA/RNA } \\
\text { Synthesis }\end{array}$ & Advanced & $\|$ & TTP & NCT03114085 & 2017 \\
\hline Temsirolimus plus Sorafenib & $\begin{array}{l}\text { mTOR+VEGFRs, KIT, } \\
\text { PDGFRs, and RAF }\end{array}$ & $\begin{array}{l}\text { Advanced; } \\
\text { First-line }\end{array}$ & $\|$ & TTP & NCT01687673 & 2012 \\
\hline Trametinib plus Sorafenib & $\begin{array}{l}\text { MEK } 1 / 2+\text { VEGFRs, KIT, } \\
\text { PDGFRs, and RAF }\end{array}$ & Advanced & 1 & MTD & NCT02292173 & 2014 \\
\hline CVM-1118 plus Sorafenib & $\begin{array}{l}\text { VM + VEGFRs, KIT, } \\
\text { PDGFRs, and RAF }\end{array}$ & Advanced & $\|$ & ORR & NCT03582618 & 2018 \\
\hline mFOLFOX plus Sorafenib & $\begin{array}{l}\text { DNA Synthesis+VEGFRs, } \\
\text { KIT, PDGFRs, and RAF }\end{array}$ & / & $\|$ & TTP & NCT01775501 & 2013 \\
\hline Erlotinib plus Bevacizumab & EGFR+VEGFA & $\begin{array}{l}\text { Advanced; } \\
\text { Second-line }\end{array}$ & $\|$ & PFS (16W) & NCT01180959 & 2011 \\
\hline TRC 105 plus Sorafenib & $\begin{array}{l}\text { Endoglin+VEGFRs, KIT, } \\
\text { PDGFRs, and RAF }\end{array}$ & / & $|/| \mid$ & MTD/ORR & NCT02560779 & 2016 \\
\hline Enzalutamide plus Sorafenib & $\begin{array}{l}A R+V E G F R s, K I T \\
\text { PDGFRs, and RAF }\end{array}$ & $\begin{array}{l}\text { Advanced; } \\
\text { First-line }\end{array}$ & $|/| \mid$ & PFS & NCT02642913 & 2015 \\
\hline $\begin{array}{l}\text { Napabucasin or Amcasertib } \\
\text { plus Sorafenib }\end{array}$ & $\begin{array}{l}\text { STAT3, cancer stemness } \\
\text { kinase+VEGFRs, KIT, } \\
\text { PDGFRs, and RAF }\end{array}$ & $\begin{array}{l}\text { Advanced; } \\
\text { First-line }\end{array}$ & $|/| \mid$ & RP2D/AEs/AA & NCT02279719 & 2014 \\
\hline ADI-PEG 20 plus FOLFOX & $\begin{array}{l}\text { Arginine+DNA } \\
\text { Synthesis }\end{array}$ & Advanced & $|/| \mid$ & ORR & NCT02102022 & 2014 \\
\hline $\begin{array}{l}\text { FATE-NK100 plus Cetuximab or } \\
\text { Trastuzumab }\end{array}$ & $\begin{array}{l}\text { NK cell immunotherapy } \\
\text { +EGFR or EGFR2 }\end{array}$ & $\begin{array}{l}\text { EGFR1+ or HER2+; } \\
\text { Advanced }\end{array}$ & 1 & $\mathrm{DLT}$ & NCT03319459 & 2018 \\
\hline Navitoclax plus Sorafenib & $\begin{array}{l}\text { BCl-2 + VEGFRs, KIT, PDGFRs, } \\
\text { and RAF }\end{array}$ & $\begin{array}{l}\text { Relapsed or } \\
\text { refractory }\end{array}$ & I & MTD/AES & NCT02143401 & 2014 \\
\hline
\end{tabular}

Abbreviations: $P D-1$ programmed cell death-1, VEGFR vascular endothelial growth factor receptor, VEGF vascular endothelial growth factor, $P D-L 1$ programmed cell death ligand 1, FGFR fibroblast growth factor receptor, FGF fibroblast growth factor, PDGFR platelet derived growth factor receptor, CTLA-4 cytotoxic T lymphocyte-associated antigen-4, TIM-3 T-Cell immunoglobulin and mucin domain-containing molecule 3, PS phosphatidylserine, IDO1 indoleamine 2,3Dioxygenase 1, GITR glucocorticoid-induced tumor necrosis factor receptor, TBRI transforming growth factor beta receptor 1, CRBN cereblon, DNMT DNA methyltransferase, Hsp90 heat shock protein 90, TGF- $\beta$ transforming growth factor beta, PI3K phosphatidylinositol 3-kinase, mTOR mechanistic target of rapamycin kinase, VM vasculogenic mimicry, EGFR epidermal growth factor receptor, AR androgen receptor, STAT3 signal transducer and activator of transcription 3, OS overall survival, PFS progress free survival, MTD maximum tolerated dose, ORR objective response rate, RP2D recommended phase II dose, $A E s$ adverse events, $D L T$ dose limited toxicity, TTP time to progress, $A A$ antitumor activity, RFS recurrence free survival

(NCT04720716). Other combination therapies are summarized in Table 2.

\section{Icaritin}

Icaritin is a prenylflavonoid compound that is extracted from epimedium. Icaritin selectively modulates ERa36 and inhibits the initiation and growth of HCC through the IL-6/JAK2/STAT3 pathway [68]. More importantly, icaritin also plays an immunomodulatory role and inhibits PD-L1 expression [69, 70]. Given that basic studies have shown that icaritin has a promising anticancer effect, icaritin was tested in a phase I trial as an oral 
immune-modulating agent for HCC (NCT02496949). The results of this trial indicated that the median OS was 192 days, TTP was 141 days, and the toxicity was manageable [71]. Treatment benefit was observed in $46.7 \%$ of the patients, including a partial response rate of $6.7 \%$ and stable disease rate of $40 \%$ [71]. Among the patients who benefited from the treatment, the median OS was 488 days, preliminarily demonstrating the survival benefit of icaritin for patients with HCC [71]. Moreover, immune-inflammation dynamic biomarker analysis showed that reduced neutrophils and increased lymphocytes indicated better TTP, and a decrease in the ratio of platelets to lymphocytes was beneficial to OS [71]. Currently, icaritin is being evaluated for HCC in two phase III trials. (NCT03236649, NCT03236636).

\section{Agents in phase $\mathrm{I} / \mathrm{II}$ trials FGF19/FGFR4 signaling pathway}

Fibroblast growth factor 19 (FGF19) and its receptor, fibroblast growth factor receptor 4 (FGFR4), are overexpressed in HCC and promote HCC progression by inhibiting apoptosis and promoting proliferation and invasion [72, 73]. In 2018, researchers improved the properties of BLU9931, the first small-molecule irreversible inhibitor that specifically targets FGFR4 in HCC, to design a novel, highly selective oral FGFR4 inhibitor, BLU554 (also known as fisogatinib) [74, 75]. Subsequently, a BLU554 was evaluated in a biomarker-based phase I trial for patients with FGF19 IHC+ advanced HCC (NCT02508467). The interim report of this trial showed a promising outcome with an ORR of $16 \%$ and DCR of $68 \%[75,76]$. Currently, BLU554 plus the antiPD-L1 mAb CS1001 is being tested in a phase I/II trial for HCC (NCT04194801). Another FGFR4-selective inhibitor, H3B-6527, is also being evaluated in a phase I trial for HCC (NCT02834780). Compared with early FGFR4 inhibitors, H3B-6527 possesses a more powerful affinity for FGFR4, higher FGFR4 selectivity, and outstanding antitumor activity [75]. Furthermore, the cyclin-dependent kinase 4/6 (CDK4/6) inhibitor palbociclib facilitated tumor regression in combination with H3B-6527 in a xenograft model of HCC, which indicates a potential new strategy for HCC treatment [77].

\section{PISK/AKT/mTOR signaling pathway}

The phosphoinositide 3-kinase (PI3K)/AKT/mammalian target of rapamycin $(m T O R)$ pathway is the downstream signaling pathway of many receptor tyrosine kinases (VEGFR, EGFR, PDGFR, and IGF-1R) [78, 79]. It plays a dominant role in regulating cell growth and cancer survival [78].

SF1126, a new RGDS-conjugated LY294002 prodrug, exerts an antitumor role through dual PI3K/BRD4 inhibition and RAS/RAF/MAPK pathway blockade [80, 81].
In 2012, a phase I trial report indicated that SF1126 is well-tolerated by patients with advanced malignancies [82]. Subsequent preclinical research also confirmed the anti-HCC activity of SF1126 alone or in combination with sorafenib in vitro and in vivo, which provided key support for the evaluation of SF1126 in further trials for HCC [81]. Additionally, increasing evidence has shown that PI3K blockade facilitates the improvement of tumor susceptibility to immunotherapy [83, 84]. A phase I trial combining SF1126 with nivolumab for advanced HCC is actively underway (NCT03059147). Everolimus is a rapamycin analog that targets mTOR. However, everolimus failed to improve the OS of patients with HCC in the 2014 phase III EVOLVE-1 trial [85]. Recently, the pan-mTOR inhibitor sapanisertib (also known as MLN0128) was evaluated in an ongoing randomized phase I/II trial in patients with advanced or metastatic HCC (NCT02575339) [86]. Notably, a study shed light on the synergetic role of PD-1 inhibition and sapanisertib in suppressing HCC growth by eIF4E- and S6-mediated mechanisms [87]. Further clinical trials are needed to validate the combination efficacy of these agents for HCC.

\section{TGF- $\beta$ pathway}

Transforming growth factor- $\beta$ (TGF- $\beta$ ) is a tumor suppressor during the early phase of carcinogenesis and promotes cancer development during the late phase by inducing epithelial-to-mesenchymal transition and other mechanisms $[88,89]$. Despite these two opposite roles, targeting the TGF- $\beta$ pathway is still a promising strategy for cancer therapy. Galunisertib (LY2157299) is a small molecule inhibitor of TGF- $\beta 1$ receptor type I. Studies have shown that galunisertib significantly disturbs HCC progression, and its combined use with sorafenib enhances the suppressive effect on HCC by overcoming sorafenib resistance [90, 91]. Based on these preclinical studies' optimistic outcomes, a galunisertib was tested in a phase I/II trial as a monotherapy or in combination with sorafenib for HCC (NCT01246986). The trial results first demonstrated that galunisertib was welltolerated, and low baseline AFP (AFP $<1.5 \times \mathrm{ULN})$ and AFP or TGF- $\beta$ responders $(>20 \%$ decrease from baseline) had better survival [92]. Subsequently, the results of galunisertib combined with sorafenib treatment showed that the TTP was 4.1 months, and the median OS reached 18.8 months in the $150 \mathrm{mg}$ galunisertib combination cohort [93]. In the subgroup analysis, the TTP of the baseline AFP $\geq 400 \mathrm{ng} / \mathrm{mL}$ group or TGF- $\beta \geq 1956$ $\mathrm{pg} / \mathrm{mL}$ baseline median group was longer than that of the group below the median [93]. Furthermore, AFP responders had poorer OS than nonresponders (17.9 versus 20.6 months), while the OS of TGF- $\beta$ responders was significantly longer than that of nonresponders ( 22.8 versus 12 months) [93]. Therefore, both baseline and 
response levels of AFP and TGF- $\beta$ could be prognostic factors of survival. In addition, a preclinical study demonstrated that galunisertib enabled the regulation of $\mathrm{T}$ cell immunity and synergized with the antitumor effect of PD-1/L1 inhibitors [94]. Currently, galunisertib in combination with nivolumab for $\mathrm{HCC}$ is being evaluated in a phase I/II trial (NCT02423343).

\section{Immune checkpoint bispecific antibodies (bsAbs)}

Although CTLA-4, an immune checkpoint, has achieved long-lasting efficacy in tumors, severe immune-related toxicity limits its application [95]. At present, bsAbs are a promising and practical strategy to improve the therapeutic response and decrease immune-related AEs [96]. Recently, researchers designed a novel bsAb, AK104, that targets CTLA-4 and PD- 1 . The results of a phase I trial demonstrated that AK104 showed controllable safety and promising efficacy in advanced solid tumors, with an ORR of $28.6 \%$ and DCR of $47.6 \%$ in the group treated with doses $\geq 2 \mathrm{mg} / \mathrm{kg}$ (NCT03261011) [97]. Subsequently, AK104 combined with chemotherapy also presented an ORR of $57.9 \%$ and DCR of $94.7 \%$ in a phase I/II trial for advanced gastric and gastroesophageal junction cancer, which indicated the great potential of AK104 in combination with chemotherapy for cancer therapy [98]. Currently, the efficacy and safety of AK104 alone or in combination with lenvatinib for advanced HCC are being evaluated in two phase I/II trials (NCT04728321, NCT04444167). Another monovalent CTLA-4/PD-1 bsAb, MEDI5752, is also being actively tested in a phase I trial of advanced solid tumors (NCT03530397) [99]. Additionally, multiple innovative bsAbs for HCC treatment have been designed and developed in preclinical studies. For example, KN046 is a novel CTLA-4/PD-L1 bsAb, and is being tested in combination with TKIs for HCC in two phase I/II trials (NCT04542837, NCT04601610). Another bsAb targeting glypican 3 (GPC3) and CD47 can strengthen innate immune responses, which provides new insight and a potential new strategy for HCC therapy [100].

\section{Adoptive cell transfer (ACT)}

CAR-T cell therapy is an ACT approach involving the injection of $\mathrm{T}$ cells genetically engineered to express chimeric antigen receptors (CARs) that specifically recognize and target tumors [101, 102]. GPC3-specific CAR-T cells directly target GPC3, the effective epitope for HCC therapy, to exert an antitumor role [103, 104]. Presently, a relevant clinical trial is underway (NCT02905188). Notably, off-target toxicity and tumor heterogeneity are major concerns that present critical safety and efficacy issues. It was recently proposed that the disruption of PD-1 can enhance the persistence and infiltration of CAR-T cells into tumors and boost their
anti-HCC effect, which provides a unique combination strategy for HCC treatment $[105,106]$. IMA202, which utilizes the $\mathrm{T}$ cell receptor (TCR) gene extracted from tumor-reactive $\mathrm{T}$ cell clones to target tumor-specific antigens by genetically engineered internal normal $\mathrm{T}$ lymphocytes, was evaluated in another trial (NCT03441100) [107]. The different antigen recognition mechanisms between TCRs and CARs affect the types of target antigen and tumor evasion [108].

\section{Oncolytic viruses}

The principle of oncolytic virotherapy is the genetic modification of a virus to strengthen its specific cellular tropism, thereby allowing it to selectively replicate within cancer cells and induce tumor immunity, which results in tumor cell lysis and death without harming normal tissues $[109,110]$. JX-594 (also known as Pexa$\mathrm{Vec}$ ) is an engineered vaccinia virus that selectively targets tumors by inactivating viral thymidine kinase (vTK) [111]. In previous clinical trials, JX-594 was shown to obtain good results in HCC treatment [111, 112]. However, the results of a subsequent randomized phase III trial, PHOCUS, in which JX-594 in combination with sorafenib was evaluated for HCC treatment, demonstrated that JX-594 did not improve treatment efficacy (NCT02562755) [113]. JX-594 combined with nivolumab is currently being tested in an ongoing phase I/II trial as a first-line treatment for advanced HCC (NCT03071094). Additionally, T-Vec (talimogene laherparepvec), a genetically engineered herpes simplex virus type I (HSV-1) [114], in combination with pembrolizumab treatment, is being tested in a phase I/II trial for HCC (NCT02509507).

\section{Emerging targets in preclinical trials}

The exploration and excavation of novel targets is now a hot topic. In 2019, Tomas-Loba et al. [115] were surprised to find a new function of the $\mathrm{p} 38 \mathrm{\gamma}$ protein in cell cycle regulation and hepatocarcinogenesis. This protein is highly similar in structure and mechanism to the CDK family, which is essential for controlling cell cycle progression [115]. Their research demonstrated that P38y strongly inhibits the proliferation of $\mathrm{HCC}$ and acts as a potential therapeutic target for HCC [115]. NKG2A, expressed by NK cells and CD8+ T cells, serves as a novel immune checkpoint [116]. In 2018, van Montfoort et al. [117] showed that blocking NKG2A improved cancer vaccines' clinical effect. Another study also revealed that the combination of anti-NKG2A and anti-PD-1/PD$\mathrm{L} 1$ promoted antitumor activity by inducing $\mathrm{CD} 8^{+} \mathrm{T}$ cell memory [118]. Monalizumab is a humanized IgG4 antibody that specifically targets NKG2A and has been clinically evaluated in several cancers (NCT02921685, NCT02643550). TIGIT and CD96, which, together with 
the costimulatory receptor $\mathrm{CD} 226$, are akin to the CD28/CTLA-4 axis, have been shown that induce an antitumor immune response [119]. Furthermore, Schooten et al. [120] presented a unique cancer intracellular epitope-MAGE-A, which is expressed by multiple tumors of various histological origins and might be a meaningful immunotherapy target. Researchers also recently revealed that PCSK9, a critical negative regulator of lowdensity lipoprotein receptor (LDLR) that facilitates the degradation of LDLR, is associated with the regulation of $\mathrm{T}$ cell infiltration and $\mathrm{CD} 8^{+} \mathrm{T}$ cell immunosuppression in tumors [121, 122]. More importantly, PCSK9, an approved clinical treatment target for hypercholesterolemia with well-known toxicity profiles, significantly enhances the antitumor effect of anti-PD-1 antibodies [121, 122]. Thus, PCSK9 is another potential target for cancer immunotherapy.

\section{Agents for HCC treatment in China}

In China, there were approximately 364,800 newly diagnosed cases of liver cancer and 318,800 liver cancerrelated deaths in 2014; patients with liver cancer in China accounted for approximately $55 \%$ of the global liver cases [123]. Despite the fact that the incidence and mortality of HCC in China have decreased in recent years due to the popularization of infant vaccination and the control of viral infections, the number of patients with HCC remains substantial [123, 124]. As a result, research related to HCC treatment is of particular interest in China.

\section{Systemic treatment}

In 2017, the Chinese Society of Clinical Oncology (CSCO) reported the Chinese subgroup's outcome in the REFLECT trial of lenvatinib. The median OS was prolonged by 4.8 months for patients with HCC [17]. A rational explanation for this improvement is that lenvatinib has advantages in survival benefit for HBVrelated HCC and HBV infection is the most frequent cause of hepatocarcinogenesis in China [1]. Furthermore, the secondary endpoints of the lenvatinib group were improved relative to the sorafenib group [17] (Table 1). Consequently, in 2018, lenvatinib was recommended as the first-line treatment for advanced HCC in China in the CSCO guidelines for hepatocellular carcinoma.

Substantial progress has been made in China in the development of ICIs and their application for the treatment of HCC. Toripalimab is an anti-PD-1 mAb developed by TopAlliance Biosciences Co., Ltd. In December 2018, toripalimab was approved by the National Medical Products Administration (NMPA) in China as a secondline treatment for unresectable or metastatic melanoma [125]. As the first anti-PD-1 mAb self-developed by China, toripalimab is of extraordinary significance. Subsequently, toripalimab was tested in various cancers and achieved positive outcomes in some [126-128]. Presently, several trials evaluating toripalimab as a treatment for HCC are underway (NCT03859128, NCT03867370). Tislelizumab (BGB-A317) is another anti-PD-1 mAb designed by BeiGene Co., Ltd. Tislelizumab is being evaluated in an ongoing phase III trial as a first-line treatment for patients with advanced HCC (NCT03412773). The main difference between tislelizumab and other general checkpoint inhibitors such as nivolumab is that other inhibitors possess the IgG4 $4_{\text {s228p }}$ heavy chain, which maintains FcyR-binding function, whereas tislelizumab does not, and can be prevented from binding to macrophages (containing $\mathrm{Fc} \gamma \mathrm{R}$ ) that kill $\mathrm{T}$ cells and suppress the antitumor function [129]. The HengRui Medicine Co., Ltd. designed an anti-PD-1 mAb SHR-1210 (also known as camrelizumab). In 2019, they conducted a phase III trial to evaluate SHR-1210 plus apatinib as a first-line treatment for advanced HCC in China (CTR20182528). This trial was based on an encouraging outcome from a previously discussed phase I trial [65]. Subsequently, SHR1210 was assessed in a phase II trial for advanced HCC performed at 13 study sites in China [130]. The results were favorable, with an ORR of $14.7 \%$, a 6-month OS of $74.4 \%$, and good antitumor activity in pretreated Chinese patients with advanced HCC, promoting the approval of SHR-1210 as a second-line treatment for advanced HCC in China [130]. The previously discussed CTLA-4/PD-1 bsAb AK104 was also independently researched and developed by Akeso, Inc. in China. Other agents being tested in clinical trials in China are summarized in Table 3.

\section{Traditional Chinese medicine}

The TCM has a long history and has been widely applied for the treatment of various diseases. A variety of TCMs have been used for HCC treatment in China for many years with certain efficacy and good safety, including elemene, cinobufotalin, and kanglaite injection, despite the lack of high-quality and multicenter clinical trials [131]. PHY906 is a Chinese herbal formula that was developed from the Huang Qin Tang herbal mixture [132]. It consists of the following four herbal ingredients: Glycyrrhiza uralensis Fisch, Paeonia lactiflora Pall, Scutellaria baicalensis Georgi, and Ziziphus jujuba Mill [132]. The results of previous early-phase trials showed promising efficacy of PHY906 combined with capecitabine for HCC $[133,134]$. The results of preclinical studies also indicated that PHY906 enhanced the anti-HCC efficacy of sorafenib by promoting tumor apoptosis and autophagy and regulating inflammation in the tumor microenvironment (TME) [132]. PHY906 is being evaluated in a phase II trial in combination with sorafenib for HCC (NCT04000737). Other TCMs under clinical trials are summarized in Table 3. 
Table 3 The ongoing clinical trials of hepatocellular carcinoma (HCC) in China

\begin{tabular}{|c|c|c|c|c|c|c|c|c|}
\hline Agent & Targets & $\begin{array}{l}\text { Conditions } \\
\text { and Stage }\end{array}$ & Phase & $\begin{array}{l}\text { Primary } \\
\text { endpoint(s) }\end{array}$ & Biomarker & Companies & ID number ${ }^{a}$ & Studystart \\
\hline \multicolumn{9}{|l|}{ Immunotherapy } \\
\hline Pembrolizumab & PD-1 & $\begin{array}{l}\text { Advanced; } \\
\text { Second-line }\end{array}$ & III & OS & / & $\begin{array}{l}\text { Merck Sharp \& Dohme } \\
\text { Corp. }\end{array}$ & CTR20160696 & 2017 \\
\hline $\begin{array}{l}\text { Tislelizumab } \\
\text { (BGB-A317) }\end{array}$ & PD-1 & $\begin{array}{l}\text { Unresectable; } \\
\text { First-line }\end{array}$ & III & OS/Safety & / & BeiGene. & NCT03412773 & 2017 \\
\hline $\begin{array}{l}\text { Toripalimab } \\
\text { (JSO01) }\end{array}$ & PD-1 & $\begin{array}{l}\text { Complete } \\
\text { resection; } \\
\text { Adjuvant }\end{array}$ & $\|/\|$ & RFS & / & $\begin{array}{l}\text { TopAlliance } \\
\text { Biosciences Inc. }\end{array}$ & NCT03859128 & 2019 \\
\hline $\begin{array}{l}\text { Camrelizumab } \\
\text { (SHR-1210) }\end{array}$ & PD-1 & $\begin{array}{l}\text { Advanced; } \\
\text { Second-line }\end{array}$ & $\|$ & $\begin{array}{l}\text { ORR/OS }(6 \\
M)\end{array}$ & / & $\begin{array}{l}\text { Jiangsu HengRui } \\
\text { Medicine Co., Ltd. }\end{array}$ & NCT02989922 & 2016 \\
\hline CAR-T cell & EрCAM & $\begin{array}{l}\text { EpCAM } \\
\text { positive }\end{array}$ & $|/| \mid$ & Toxicity & / & $\begin{array}{l}\text { First Affiliated Hospital } \\
\text { of Chengdu Medical } \\
\text { College. }\end{array}$ & NCT03013712 & 2017 \\
\hline $\begin{array}{l}\text { Infusion of iNKT } \\
\text { cells and } C D 8^{+} T \\
\text { cells }\end{array}$ & Lysis tumor cells & Advanced & $|/| \mid$ & AEs/ORR & / & $\begin{array}{l}\text { Shanghai Public Health } \\
\text { Clinical Center. }\end{array}$ & NCT03093688 & 2017 \\
\hline KN035 & PD-L1 & Advanced & I & $\begin{array}{l}\text { DLTs/AEs/ } \\
\text { ORR }\end{array}$ & / & $\begin{array}{l}\text { 3D Medicines (Sichuan) } \\
\text { Co., Ltd.; Alphamab Co., } \\
\text { Ltd. }\end{array}$ & NCT03101488 & 2017 \\
\hline $\begin{array}{l}\text { GLS-010 } \\
\text { injection }\end{array}$ & PD-1 & Advanced & । & AEs/AA & PD-L1 & $\begin{array}{l}\text { Harbin Gloria } \\
\text { Pharmaceutical Co., Ltd. }\end{array}$ & CTR20170692 & 2017 \\
\hline iNKT cells & Lysis tumor cells & $\begin{array}{l}\text { Relapsed, } \\
\text { advanced }\end{array}$ & । & AEs & / & Beijing YouAn Hospital. & NCT03175679 & 2017 \\
\hline $\begin{array}{l}\text { ET1402L1-CAR-T } \\
\text { cells }\end{array}$ & AFP & $\begin{array}{l}\text { AFP+, } \\
\text { advanced }\end{array}$ & । & DLT/Toxicity & AFP & $\begin{array}{l}\text { Aeon Therapeutics } \\
\text { (Shanghai) Co., Ltd. }\end{array}$ & NCT03349255 & 2017 \\
\hline $\begin{array}{l}\text { GPC3-T2-CAR-T } \\
\text { cells }\end{array}$ & GPC3 & GPC3+ & । & DLT & / & $\begin{array}{l}\text { Second Affiliated } \\
\text { Hospital of Guangzhou } \\
\text { Medical University. }\end{array}$ & NCT03198546 & 2017 \\
\hline \multicolumn{9}{|l|}{ Anti-angiogenesis } \\
\hline Donafenib & VEGFR, PDGFR, RAF & $\begin{array}{l}\text { Advanced; } \\
\text { First-line }\end{array}$ & III & OS & / & $\begin{array}{l}\text { Suzhou Zelgen } \\
\text { Biopharmaceuticals Co., } \\
\text { Ltd. }\end{array}$ & NCT02645981 & 2016 \\
\hline $\begin{array}{l}\text { Lenvatinib } \\
\text { (E7080) }\end{array}$ & $\begin{array}{l}\text { VEGFR1-3, FGFR1-4, } \\
\text { PDGFR a, RET, and } \\
\text { KIT }\end{array}$ & $\begin{array}{l}\text { Unresectable; } \\
\text { First-line }\end{array}$ & III & OS & / & Eisai Co., Ltd. & CTR20131648 & 2014 \\
\hline $\begin{array}{l}\text { Muparfostat (PI- } \\
\text { 88) }\end{array}$ & FGF1-2, VEGF & $\begin{array}{l}\text { Resected; } \\
\text { Adjuvant }\end{array}$ & III & DFS & / & $\begin{array}{l}\text { Medigen Biotechnology } \\
\text { Corp. }\end{array}$ & CTR20131019 & 2015 \\
\hline $\begin{array}{l}\text { Brivanib (ZL- } \\
\text { 2301) }\end{array}$ & VEGFR, FGFR & $\begin{array}{l}\text { Advanced; } \\
\text { Second-line }\end{array}$ & $\|$ & DCR $(3 \mathrm{M})$ & / & $\begin{array}{l}\text { Zai Lab Pharmaceutical } \\
\text { (Shanghai) Co., Ltd. }\end{array}$ & CTR20170216 & 2017 \\
\hline $\begin{array}{l}\text { Lucitanib } \\
\text { (AL3810) }\end{array}$ & FGFR1-2, VEGFR1-3 & $\begin{array}{l}\text { Advanced or } \\
\text { metastatic }\end{array}$ & $\mathrm{lb}$ & $A E$ & / & $\begin{array}{l}\text { Shanghai Institute of } \\
\text { Materia Medica; } \\
\text { Academia Sinica. }\end{array}$ & CTR20160271 & 2016 \\
\hline $\begin{array}{l}\text { Metatinib } \\
\text { Trometamol } \\
\text { tablets }\end{array}$ & METNEGFR2 & $\begin{array}{l}\text { Advanced or } \\
\text { metastatic }\end{array}$ & $\mathrm{Ib}$ & $A E$ & MET & $\begin{array}{l}\text { Simcere Pharmaceutical } \\
\text { Co., Ltd. }\end{array}$ & CTR20150743 & 2015 \\
\hline Chiauranib & $\begin{array}{l}\text { VEGFR, PDGFRa, KIT, } \\
\text { Aurora B and CSF-1R }\end{array}$ & Advanced & । & $\operatorname{PFR}(16 \mathrm{~W})$ & / & $\begin{array}{l}\text { Chipscreen Biosciences, } \\
\text { Ltd. }\end{array}$ & NCT03245190 & 2018 \\
\hline \multicolumn{9}{|c|}{ Cell cycle inhibitors and Anti-proliferation } \\
\hline $\begin{array}{l}\text { Erdafitinib (JNJ- } \\
\text { 42756493) }\end{array}$ & FGFR & $\begin{array}{l}\text { Advanced; } \\
\text { FGF19 } \\
\text { amplification }\end{array}$ & $|/| \mid$ & $\mathrm{RP} 2 \mathrm{D} / \mathrm{ORR}$ & / & $\begin{array}{l}\text { Janssen Research \& } \\
\text { Development, LLC. }\end{array}$ & NCT02421185 & 2015 \\
\hline $\begin{array}{l}\text { ATG-008 (CC- } \\
\text { 223) }\end{array}$ & mTORC1/2 & $\begin{array}{l}\text { HBV+, } \\
\text { Advanced; } \\
\text { Second-line }\end{array}$ & $\|$ & PK/AEs/ORR & $\begin{array}{l}\text { TORC1/2 } \\
\text { and others }\end{array}$ & Antengene Corporation. & NCT03591965 & 2018 \\
\hline
\end{tabular}


Table 3 The ongoing clinical trials of hepatocellular carcinoma (HCC) in China (Continued)

\begin{tabular}{|c|c|c|c|c|c|c|c|c|}
\hline Agent & Targets & $\begin{array}{l}\text { Conditions } \\
\text { and Stage }\end{array}$ & Phase & $\begin{array}{l}\text { Primary } \\
\text { endpoint(s) }\end{array}$ & Biomarker & Companies & ID number ${ }^{\mathrm{a}}$ & Studystart \\
\hline \multicolumn{9}{|c|}{ Combination therapy } \\
\hline $\begin{array}{l}\text { PD-1 Antibody } \\
\text { Plus Lenvatinib }\end{array}$ & $\begin{array}{l}\text { PD-1 + VEGFR1-3, } \\
\text { FGFR1-4, PDGFR a, } \\
\text { RET, and KIT }\end{array}$ & Advanced & III & OS & / & Sun Yat-sen University. & NCT03744247 & 2019 \\
\hline $\begin{array}{l}\text { HLX10 plus } \\
\text { HLX04 }\end{array}$ & PD-1+ VEGF & $\begin{array}{l}\text { Locally } \\
\text { Advanced or } \\
\text { Metastatic; } \\
\text { First-line }\end{array}$ & III & OS/PFS & / & $\begin{array}{l}\text { Shanghai Henlius } \\
\text { Biotech. }\end{array}$ & NCT04465734 & 2020 \\
\hline $\begin{array}{l}\text { Durvalumab } \\
\text { plus } \\
\text { Tremelimumab }\end{array}$ & PD-L1 + CTLA-4 & $\begin{array}{l}\text { Unresectable; } \\
\text { First-line }\end{array}$ & III & OS/AE & / & Medlmmune LLC. & CTR20180607 & 2018 \\
\hline $\begin{array}{l}\text { SHR-1210 plus } \\
\text { FOLFOX } 4\end{array}$ & $\begin{array}{l}\text { PD-1 + DNA } \\
\text { Synthesis }\end{array}$ & $\begin{array}{l}\text { Advanced; } \\
\text { First-line }\end{array}$ & III & OS & / & $\begin{array}{l}\text { Jiangsu HengRui } \\
\text { Medicine Co., Ltd. }\end{array}$ & NCT03605706 & 2018 \\
\hline $\begin{array}{l}\text { SHR-1210 plus } \\
\text { Apatinib }\end{array}$ & PD-1 + VEGFR-2 & $\begin{array}{l}\text { Advanced; } \\
\text { First-line }\end{array}$ & III & OS/PFS & / & $\begin{array}{l}\text { Shanghai HengRui } \\
\text { Medicine Co., Ltd. }\end{array}$ & CTR20182528 & 2019 \\
\hline $\begin{array}{l}\text { Sintilimab plus } \\
\text { IBI305 }\end{array}$ & PD-1 + VEGF & $\begin{array}{l}\text { Advanced; } \\
\text { First-line }\end{array}$ & $\|/\|$ & OS/ORR & / & $\begin{array}{l}\text { Innovent Biologics } \\
\text { (Suzhou) Co. Ltd. }\end{array}$ & NCT03794440 & 2019 \\
\hline $\begin{array}{l}\text { AK105 plus } \\
\text { Anlotinib or } \\
\text { AK105 plus } \\
\text { Bevacizumab }\end{array}$ & $\begin{array}{l}\text { PD-1 + VEGFR, PDGF } \\
\text { R, FGFR, KIT or PD- } \\
1+\text { VEGFA }\end{array}$ & $\begin{array}{l}\text { Unresectable; } \\
\text { First-line }\end{array}$ & $\mid \mathrm{b} / \|$ & ORR & / & $\begin{array}{l}\text { Akeso (Guangdong) } \\
\text { Biopharma, Inc. }\end{array}$ & CTR20182026 & 2018 \\
\hline $\begin{array}{l}\text { PD-1 mAb plus } \\
\text { PolylC }\end{array}$ & PD-1 + TLR3 & Unresectable & $\|$ & ORR & AFP & $\begin{array}{l}\text { Second Affiliated } \\
\text { Hospital, School of } \\
\text { Medicine, Zhejiang } \\
\text { University. }\end{array}$ & NCT03732547 & 2018 \\
\hline $\begin{array}{l}\text { PHY906 plus } \\
\text { Sorafenib }\end{array}$ & $\begin{array}{l}\text { Chinese herbal } \\
\text { formulation+VEGFRs, } \\
\text { KIT, PDGFRs, and RAF }\end{array}$ & Advanced & 1 & RP2D & / & $\begin{array}{l}\text { City of Hope Medical } \\
\text { Center. }\end{array}$ & NCT01666756 & 2013 \\
\hline \multicolumn{9}{|c|}{ Traditional Chinese medicine } \\
\hline $\begin{array}{l}\text { Xihuang } \\
\text { Capsules }\end{array}$ & / & Resected & IV & $\begin{array}{l}\text { recurrence } \\
\text { rate }\end{array}$ & / & $\begin{array}{l}\text { Shuqun Cheng, Eastern } \\
\text { Hepatobiliary Surgery } \\
\text { Hospital. }\end{array}$ & NCT02399033 & 2015 \\
\hline Icaritin & ERa36 & $\begin{array}{l}\text { Advanced; } \\
\text { HBV-Related }\end{array}$ & III & OS & $\begin{array}{l}\text { PD-L1, } \\
\text { hnRNPAB1, } \\
\text { IL-6 and } \\
\text { others }\end{array}$ & $\begin{array}{l}\text { Beijing Shenogen } \\
\text { Biomedical Co., Ltd. }\end{array}$ & NCT03236636 & 2017 \\
\hline Icaritin & ERa36 & $\begin{array}{l}\text { PD-L1+, } \\
\text { advanced }\end{array}$ & III & OS & $\begin{array}{l}\text { PD-L1, } \\
\text { hnRNPAB1, } \\
\text { IL-6 and } \\
\text { others }\end{array}$ & $\begin{array}{l}\text { Beijing Shenogen } \\
\text { Biomedical Co., Ltd. }\end{array}$ & NCT03236649 & 2017 \\
\hline $\begin{array}{l}\text { Ursolic acid } \\
\text { nanoliposomes } \\
\text { injection }\end{array}$ & IKK $\beta$ & Advanced; & । & ORR & / & $\begin{array}{l}\text { Wuhan Liyuanheng } \\
\text { Pharmaceutical Co., Ltd. }\end{array}$ & CTR20140395 & 2016 \\
\hline $\begin{array}{l}\text { Chlorogenic } \\
\text { acid }\end{array}$ & cell cycle & Advanced; & । & DLT/MTD & / & $\begin{array}{l}\text { Sichuan Jiuzhang } \\
\text { Biotech Co., Ltd. }\end{array}$ & CTR20130586 & 2014 \\
\hline $\begin{array}{l}\text { Jiu-wei-zhen- } \\
\text { xiao Granule }\end{array}$ & I & $\begin{array}{l}\text { Advanced; } \\
\text { Unresectable }\end{array}$ & । & PFS & / & $\begin{array}{l}\text { Zhong Wang, China } \\
\text { Academy of Chinese } \\
\text { Medical Sciences. }\end{array}$ & NCT03851471 & 2019 \\
\hline \multicolumn{9}{|l|}{ Other mechanisms } \\
\hline $\begin{array}{l}\text { K-001 (Marine } \\
\text { biological } \\
\text { products) }\end{array}$ & $\begin{array}{l}\text { anti-inflammation, } \\
\text { anti-angiogenesis }\end{array}$ & Advanced & III & OS & AFP & $\begin{array}{l}\text { Beijing Huashi Tianfu } \\
\text { Biomedical Technology } \\
\text { Co., Ltd. }\end{array}$ & CTR20132910 & 2014 \\
\hline IFN-alpha & $\begin{array}{l}\text { pro-apoptosis, anti- } \\
\text { proliferation }\end{array}$ & $\begin{array}{l}\text { Resected; low } \\
\text { miR-26 } \\
\text { expression }\end{array}$ & III & DFS & miR-26 & Fudan University. & NCT01681446 & 2012 \\
\hline Galunisertib & TGF- $\beta$ & Advanced; & $\|$ & OS & / & Eli Lilly and Company. & CTR20150343 & 2015 \\
\hline
\end{tabular}


Table 3 The ongoing clinical trials of hepatocellular carcinoma (HCC) in China (Continued)

\begin{tabular}{|c|c|c|c|c|c|c|c|c|}
\hline Agent & Targets & $\begin{array}{l}\text { Conditions } \\
\text { and Stage }\end{array}$ & Phase & $\begin{array}{l}\text { Primary } \\
\text { endpoint(s) }\end{array}$ & Biomarker & Companies & ID number ${ }^{a}$ & Studystart \\
\hline \multicolumn{2}{|l|}{ (LY2157299) } & \multicolumn{7}{|l|}{ First-line } \\
\hline $\begin{array}{l}\text { Boanmycin } \\
\text { Hydrochloride } \\
\text { for Injection }\end{array}$ & cytotoxic agent & / & $\|$ & ORR & / & DIKANG Pharmaceutical. & CTR20140308 & 2015 \\
\hline PT-112 & $\begin{array}{l}\text { pro-apoptosis, } \\
\text { immunogenic cell } \\
\text { death inducer }\end{array}$ & Advanced & $|/| \mid$ & $\begin{array}{l}\text { AEs/DLTs/ } \\
\text { DCR }\end{array}$ & / & $\begin{array}{l}\text { SciClone } \\
\text { Pharmaceuticals. }\end{array}$ & NCT03439761 & 2018 \\
\hline Hemay 102 & cytotoxic agent & Advanced; & । & $\mathrm{AE}$ & / & $\begin{array}{l}\text { Hainan Hailing } \\
\text { Chemipharma } \\
\text { Corporation Limited. }\end{array}$ & CTR20181497 & 2018 \\
\hline ZSP1241 & / & Advanced & । & $\begin{array}{l}\text { MTD/DLT/ } \\
\text { AEs }\end{array}$ & / & $\begin{array}{l}\text { Guangdong } \\
\text { Zhongsheng } \\
\text { Pharmaceutical Co., Ltd. }\end{array}$ & NCT03734926 & 2018 \\
\hline CGX1321 & WNT & Advanced & । & AEs & / & Curegenix Inc. & NCT03507998 & 2017 \\
\hline \multicolumn{9}{|c|}{$\begin{array}{l}\text { Abbreviations: PD-1 programmed cell death-1, PD-L1 programmed cell death ligand 1, EPCAM epithelial cell adhesion molecule, AFP alpha fetoprotein, GPC3 } \\
\text { glypican 3, VEGFR vascular endothelial growth factor receptor, VEGF vascular endothelial growth factor, PDGFR platelet derived growth factor receptor, FGFR } \\
\text { fibroblast growth factor receptor, FGF fibroblast growth factor, PDGFR platelet derived growth factor receptor, CSF-1R colony stimulating factor } 1 \text { receptor, } \\
\text { mTORC1/2 mechanistic target of rapamycin kinase complex } 1 \text { and 2, TLR3 toll like receptor 3, CTLA-4 cytotoxic T lymphocyte-associated antigen-4, IKK } \beta \text { inhibitor } \\
\text { of nuclear factor kappa B kinase subunit beta, ERa36 estrogen receptor-alpha 36, TGF- } \beta \text { transforming growth factor beta, OS overall survival, RFS recurrence free } \\
\text { survival, ORR objective response rate, DLT dose limited toxicity, AEs adverse events, DFS disease free survival, DCR disease control rate, PFR progression free rate, } \\
\text { RP2D recommended phase II dose, PK pharmacokinetic, MTD maximum tolerated dose, } P F S \text { progress free survival } \\
\text { aID number: IDs starting with NCT are from clinicaltrials.gov, while IDs starting with CTR are from chinadrugtrials.org.cn/index.html }\end{array}$} \\
\hline
\end{tabular}

Due to the integration of TCM experience with modern medical theory systems, the long-term puzzles of weak absorption, low bioavailability, and apparent side effects of TCMs have been resolved gradually, for example, the development of the novel micellar system GA-PEG-SS-PLGA [135]. Furthermore, future studies need to identify the active substances in TCM compounds and explore the specific functional mechanisms of the anticancer effect of these substances. Of note, evidence-based medicine requires not only mechanistic knowledge but also clinical research. Jin-Ling Tang proposed an efficacy-driven strategy for TCM research, emphasizing that drug mechanism research can be meaningful only if it is clinically efficacious [136]. Therefore, it is also essential to promote clinical trials of traditional medicine in the future.

\section{Challenges in HCC treatment}

The efficacy of sorafenib fails to meet the expectations of better survival benefit, and although immunotherapy has been advantageous for HCC treatment, a durable and effective response only occurs in a small proportion of patients with HCC [137]. All of these facts indicate that challenges in HCC treatment still exist.

\section{Therapeutic resistance}

The survival of patients with advanced HCC treated with sorafenib is limited to 1 year [138]. This limitation may partially be attributed to drug resistance, and its potential mechanisms include the activation of EGFR, epithelial-mesenchymal transition (EMT), cancer stem cell (CSC) presence, or tumor-initiating cell (TIC) involvement [139, 140]. Furthermore, the TME plays a substantial role in the development of tumor resistance to therapeutics [141]. A variety of cells in addition to tumor cells make up the TME, which plays a suppressive role in the antitumor effect by multiple mechanisms, such as restriction of $\mathrm{T}$ cell accumulation in tumors and $\mathrm{T}$ cell exhaustion or dysfunction $[141,142]$. It is urgent to develop strategies to overcome drug resistance. First, resistance-related molecules have been targeted. Cetuximab (EGFR-targeted $\mathrm{mAb}$ ) is a preferred candidate. Despite negative outcomes in several trials, cetuximab's powerful potential is still worth exploring in the future [143]. Second, combinations of multiple agents that target different pathways have been evaluated. For example, the results of one study demonstrated that anti-CXCR4 in combination with anti-PD-1 and sorafenib is beneficial for patients with HCC [144]. Finally, predictive biomarker-based population selection is an important future topic of investigation. Genetic heterogeneity, which partially explains drug resistance, determines the significance of personalized therapy [140]. Hence, exploring predictive biomarkers facilitates the implementation of precise treatment.

\section{Biomarkers}

Although the biomarkers' pivotal role in therapy response has been emphasized for several years, clinically valuable biomarkers remain lacking. In 2016, Zhu et al. [145] developed a large-scale biomarker-related study under the phase III SEARCH trial [146]. They revealed 
that the upregulation of HGF, VEGFA, and VEGFC expression and the downregulation of plasma KIT levels were closely related to poor clinical outcomes in patients with HCC treated with sorafenib with or without erlotinib [145]. Regrettably, there has been no more indepth exploration to distinguish the clinical benefit differences between sorafenib alone or in combination with erlotinib. Additionally, many molecules, such as tumor-associated macrophages (TAMs), PD-L1, tumorinfiltrating lymphocytes (TILs), and a strategy referred to as the immunoscore, have been described as potential biomarkers for immunotherapy in cancers [147-149]. However, not all of these candidates are equally appropriate for HCC, such as PD-L1 [13]. The efficacy and clinical value of these hypothetical biomarkers remain to be verified in future trials.

\section{Treatment safety}

With the promising efficacy of immunotherapy unveiled, more clinical trials are needed to assess ICIs in various tumors. As a result, severe immune-related AEs have been discovered, in particular cardiotoxicity. In 2018, Moslehi et al. [150] analyzed 101 cases of fatal myocarditis after ICI treatment. They emphasized the high fatality risk of this $\mathrm{AE}$, especially with the combination of PD-1 and CTLA- 4 mAbs (death rate of $36 \%$ with monotherapy and $67 \%$ with the combination treatment) [150]. Previous studies also reported fulminant myocarditis in individual patients $[151,152]$. In addition, as normal tissues also express partial tumor antigens, adoptive cell treatment might harm healthy tissues by targeting these tumor antigens (also known as autoimmune toxicity) [153]. Promisingly, several tactics to resolve this problem have been proposed, including TNF- $\alpha$ - or IL-6-targeted drugs and engineered $\mathrm{T}$ cells expressing inducible suicide genes [153-156]. Additionally, engineered $\mathrm{T}$ cells expressing two kinds of CARs or TCRs are promising strategies that target two tumor antigens simultaneously and while sparing normal tissues that do not express the two malignancy-related antigens together [153-155].

\section{Conclusions}

Looking back on the history of HCC drug development, many promising drugs have failed in phase III clinical trials (summarized in Supplementary Table S1). Owing to the continuous innovation of scientific research, abundant studies related to targeted therapy of HCC have been exceedingly rewarding in recent years. Specifically, the FDA approved several antiangiogenic agents and immune checkpoint inhibitors for HCC between 2017 and 2020, and multiple agents are being evaluated in current clinical trials. However, the moderate efficacy of targeted therapy, the lack of biomarkers for therapeutic responsiveness, and the limitations in achieving a durable response to immune inhibitors still exist. In the past decade, the development of sequencing technologies has boomed, in particular that of high-throughput sequencing, which has enabled rapid large-scale genome sequencing at a lower cost [157]. However, the deficiency in accuracy limits the ability of high-throughput sequencing to delineate a comprehensive molecular map; for example, it is challenging to detect rare genetic variations with this sequencing approach [158]. Precision medicine represents one of the goals of tailoring healthcare for specific patients based on their data from various technologies, in particular genetic sequencing [159]. Consequently, there will be more stringent requirements for sequencing in terms of efficiency, accuracy, stability, and low price in the future. In addition, proteomics is being advanced and perfected gradually, but the implementation of high-sensitivity and high-accuracy proteomics technology is still a challenge. Consequently, the following possible directions should be considered. (i) Elucidation of the molecular mechanisms of HCC from multiple perspectives, such as genetics and epigenetics, cell-cell interactions, and the roles of the TME. (ii) Construction of stratified treatments based on predictive biomarkers to enable individualized treatment. Josep $M$. Llovet and Virginia Hernandez-Gea discussed two trial designs related to this concept in their review [138], namely proof-of-concept trials and biomarker-based enrichment trials. They emphasized that we should not only concentrate on multitarget drugs that aimed toward eligible patients but also specific targeted drugs that target a subpopulation of patients characterized by molecular aberrations. (iii) Exploration of extracts from traditional Chinese medicines, such as artemisinin and chloroquine derivatives [160, 161]; the large number of patients with HCC in China presents an opportunity to gain more evidence of the efficacy of these drugs and experience in their application. In summary, with the increasing focus on HCC research and the rapid development of molecular biotechnology, more mysteries of HCC will be resolved comprehensively and deeply, and more treatment strategies will be presented.

\footnotetext{
Abbreviations

HCC: Hepatocellular carcinoma; TCM: Traditional Chinese medicine; FDA: United States Food and Drug Administration; PD-1: Programmed cell death-1; PD-L1: Programmed cell death ligand-1; CTLA-4: Cytotoxic T lymphocyte-associated antigen-4; ICB: Immune checkpoint blockade; ICls: Immune checkpoint inhibitors; OS: Overall survival; ORR: Objective response rate; DCR: Disease control rate; ESMO: European Society for Medical Oncology; AEs: Adverse events; mAb: Monoclonal antibody; PRR: Partial response rate; ACT: Adoptive cell transfer; CARs: Chimeric antigen receptors; TCRs: T cell receptors; GPC3: Glypican 3; vTK: Viral thymidine kinase; HSV1: Herpes simplex virus type l; HFSR: Hand-foot skin reaction; PFS: Progression-free survival; TTP: Time to progression; HAIC: Hepatic arterial infusion chemotherapy; TKI: Tyrosine kinase inhibitor; AFP: a-fetoprotein; ASCO: American Society of Clinical Oncology; FGF19: Fibroblast growth factor 19; FGFR4: Fibroblast growth factor receptor 4; PI3K: Phosphoinositide 3-kinase; mTOR: Mammalian target of rapamycin; TGF- $\beta$ : Transforming
} 
growth factor- $\beta$; bsAbs: Bispecific antibodies; CDK: Cyclin-dependent kinase; LDLR: Low-density lipoprotein receptor; EMT: Epithelial-mesenchymal transition; CSCs: Cancer stem cells; TICs: Tumor-initiating cells; TME: Tumor microenvironment; TAMs: Tumor-associated macrophages; TILs: Tumorinfiltrating lymphocytes; CSCO: Chinese Society of Clinical Oncology; NMPA: National Medical Products Administration

\section{Supplementary Information}

The online version contains supplementary material available at https://doi. org/10.1186/s13046-021-01968-w.

Additional file 1: Table S1. The agents that failed in phase III clinical trials for HCC

\section{Acknowledgments}

Not applicable.

\section{Authors' contributions}

XXH designed and finalized the study; XYL wrote the paper; KMW and XXH participated in revising the review. All authors read and approved the final manuscript.

\section{Funding}

This work was supported by the National Natural Science Foundation of China (No.81772969, 82073095).

\section{Availability of data and materials}

The datasets generated and analyzed during the current study are available in the US National Library of Medicine repository (https://clinicaltrials.gov) and the China drug trials repository (http://www.chinadrugtrials.org.cn/index. html).

\section{Declarations}

\section{Ethics approval and consent to participate}

Not applicable.

\section{Consent for publication}

Not applicable.

\section{Competing interests}

The authors declare that they have no competing interests.

\begin{abstract}
Author details
${ }^{1}$ Institute of Liver and Gastrointestinal Diseases, Tongji Hospital, Tongji Medical College, Huazhong University of Science and Technology, Wuhan 430030, China. ${ }^{2}$ Hubei Key Laboratory of Hepato-Pancreato-Biliary Diseases, Tongji Hospital, Tongji Medical College, Huazhong University of Science and Technology, Wuhan 430030, China. ${ }^{3}$ Department of Medical Oncology, The Affiliated Cancer Hospital of Zhengzhou University \& Henan Cancer Hospital, Zhengzhou 450008, China. ${ }^{4}$ Department of Oncology, Tongji Hospital of Tongji Medical College, Huazhong University of Science and Technology, Wuhan 430030, China.
\end{abstract}

Received: 9 February 2021 Accepted: 27 April 2021

Published online: 18 May 2021

\section{References}

1. Bray F, Ferlay J, Soerjomataram I, Siegel RL, Torre LA, Jemal A. Global cancer statistics 2018: GLOBOCAN estimates of incidence and mortality worldwide for 36 cancers in 185 countries. CA Cancer J Clin. 2018;68(6):394-424. https://doi.org/10.3322/caac.21492.

2. Villanueva A, Llovet JM. Targeted therapies for hepatocellular carcinoma. Gastroenterology. 2011;140(5):1410-26. https://doi.org/10.1053/j.gastro.2011. 03.006.

3. Cancer Genome Atlas Research Network, Electronic address wbe, Cancer Genome Atlas Research N. Comprehensive and Integrative Genomic Characterization of Hepatocellular Carcinoma. Cell. 2017:169(7):1327-41 e1323. https://doi.org/10.1016/j.cell.2017.05.046.

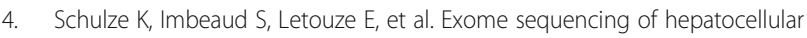
carcinomas identifies new mutational signatures and potential therapeutic targets. Nat Genet. 2015;47(5):505-11. https://doi.org/10.1038/ng.3252.

5. Hardy T, Mann DA. Epigenetics in liver disease: from biology to therapeutics. Gut. 2016;65(11):1895-905. https://doi.org/10.1136/gutjnl-2 015-311292.

6. Villanueva A, Portela A, Sayols S, Battiston C, Hoshida Y, MéndezGonzález J, et al. DNA methylation-based prognosis and epidrivers in hepatocellular carcinoma. Hepatology. 2015;61(6):1945-56. https://doi. org/10.1002/hep.27732

7. Wong CM, Tsang FH, Ng IO. Non-coding RNAs in hepatocellular carcinoma: molecular functions and pathological implications. Nat Rev Gastroenterol Hepatol. 2018;15(3):137-51. https://doi.org/10.1038/nrgastro.2017.169.

8. Gao Q, Zhu H, Dong L, Shi W, Chen R, Song Z, et al. Integrated Proteogenomic characterization of HBV-related hepatocellular carcinoma. Cell. 2019;179(2):561-77 e522. https://doi.org/10.1016/j.cell.2019.08.052

9. Jiang $Y$, Sun $A$, Zhao $Y$, et al. Proteomics identifies new therapeutic targets of early-stage hepatocellular carcinoma. Nature. 2019;567(7747):257-61. https://doi.org/10.1038/s41586-019-0987-8.

10. Zhang Q, He Y, Luo N, Patel SJ, Han Y, Gao R, et al. Landscape and dynamics of single immune cells in hepatocellular carcinoma. Cell. 2019. 179(4):829-45 e820. https://doi.org/10.1016/j.cell.2019.10.003.

11. Qin N, Yang F, Li A, Prifti $E$, Chen $Y$, Shao $L$, et al. Alterations of the human gut microbiome in liver cirrhosis. Nature. 2014;513(7516):59-64. https://doi. org/10.1038/nature13568.

12. Llovet JM, Ricci S, Mazzaferro V, Hilgard P, Gane E, Blanc JF, et al. Sorafenib in advanced hepatocellular carcinoma. N Engl J Med. 2008;359(4):378-90. https://doi.org/10.1056/NEJMoa0708857.

13. El-Khoueiry AB, Sangro B, Yau T, et al. Nivolumab in patients with advanced hepatocellular carcinoma (CheckMate 040): an open-label, non-comparative, phase 1/2 dose escalation and expansion trial. Lancet. 2017;389(10088): 2492-502. https://doi.org/10.1016/S0140-6736(17)31046-2.

14. Zhu AX, Finn RS, Edeline J, et al. Pembrolizumab in patients with advanced hepatocellular carcinoma previously treated with sorafenib (KEYNOTE-224): a non-randomised, open-label phase 2 trial. Lancet Oncol. 2018;19(7):940-52. https://doi.org/10.1016/\$1470-2045(18)30351-6.

15. Sangro B, Gomez-Martin C, de la Mata M, Iñarrairaegui M, Garralda E, Barrera $P$, et al. A clinical trial of CTLA-4 blockade with tremelimumab in patients with hepatocellular carcinoma and chronic hepatitis C. J Hepatol. 2013;59(1): 81-8. https://doi.org/10.1016/j.jhep.2013.02.022.

16. Kudo M, Finn RS, Qin S, Han KH, Ikeda K, Piscaglia F, et al. Lenvatinib versus sorafenib in first-line treatment of patients with unresectable hepatocellular carcinoma: a randomised phase 3 non-inferiority trial. Lancet. 2018; 391(10126):1163-73. https://doi.org/10.1016/S0140-6736(18)30207-1.

17. Al-Salama ZT, Syed YY, Scott L. Lenvatinib: a review in hepatocellular carcinoma. Drugs. 2019;79(6):665-74. https://doi.org/10.1007/s40265-01901116-x.

18. Bruix J, Qin S, Merle P, Granito A, Huang YH, Bodoky G, et al. Regorafenib for patients with hepatocellular carcinoma who progressed on sorafenib treatment (RESORCE): a randomised, double-blind, placebo-controlled, phase 3 trial. Lancet. 2017;389(10064):56-66. https://doi.org/10.1016/S01406736(16)32453-9.

19. Abou-Alfa GK, Meyer $T$, Cheng AL, el-Khoueiry AB, Rimassa L, Ryoo BY, et al. Cabozantinib in patients with advanced and progressing hepatocellular carcinoma. N Engl J Med. 2018:379(1):54-63. https://doi.org/10.1056/ NEJMoa1717002.

20. Zhu AX, Kang Y-K, Yen C-J, et al. REACH-2: a randomized, double-blind, placebo-controlled phase 3 study of ramucirumab versus placebo as second-line treatment in patients with advanced hepatocellular carcinoma (HCC) and elevated baseline alpha-fetoprotein (AFP) following first-line sorafenib. J Clin Oncol. 2018;36:4003.

21. Oin S. Apatinib in Chinese patients with advanced hepatocellular carcinoma: a phase II randomized, open-label trial. J Clin Oncol. 2014;32(15 suppl):4019. https://doi.org/10.1200/jco.2014.32.15 suppl.4019.

22. Finn RS, Qin S, Ikeda M, Galle PR, Ducreux M, Kim TY, et al. Atezolizumab plus Bevacizumab in Unresectable Hepatocellular Carcinoma. N Engl J Med. 2020;382(20):1894-905. https://doi.org/10.1056/NEJMoa1915745.

23. Finn RS, Ikeda M, Zhu AX, Sung MW, Baron AD, Kudo $M$, et al. Phase lb study of Lenvatinib plus Pembrolizumab in patients with Unresectable hepatocellular carcinoma. J Clin Oncol. 2020:38(26):2960-70. https://doi. org/10.1200/JCO.20.00808. 
24. Yau T, Kang YK, Kim TY, el-Khoueiry AB, Santoro A, Sangro B, et al. Efficacy and safety of Nivolumab plus Ipilimumab in patients with advanced hepatocellular carcinoma previously treated with Sorafenib: the CheckMate 040 randomized clinical trial. JAMA Oncol. 2020;6(11):e204564. https://doi. org/10.1001/jamaoncol.2020.4564.

25. FDA. FDA expands approved use of Stivarga to treat liver cancer: The U.S. Food and Drug Administration; 2017. https://www.fda.gov/news-events/ press-announcements/fda-expands-approved-use-stivarga-treat-liver-cancer. Accessed 27 Apr 2017.

26. FDA. FDA approves lenvatinib for unresectable hepatocellular carcinoma: The U.S. Food and Drug Administration; 2018. https://www.fda.gov/drugs/ resources-information-approved-drugs/fda-approves-lenvatinib-unresecta ble-hepatocellular-carcinoma. Accessed 16 Aug 2018.

27. FDA. FDA approves cabozantinib for hepatocellular carcinoma: The U.S. Food and Drug Administration; 2019. https://www.fda.gov/drugs/fda-a pproves-cabozantinib-hepatocellular-carcinoma. Accessed 12 Mar 2019.

28. FDA. FDA approves ramucirumab for hepatocellular carcinoma: The U.S. Food and Drug Administration; 2019. https://www.fda.gov/drugs/resourcesinformation-approved-drugs/fda-approves-ramucirumab-hepatocellular-ca rcinoma. Accessed 10 May 2019.

29. Hamid O, Robert C, Daud A, Hodi FS, Hwu WJ, Kefford R, et al. Safety and tumor responses with lambrolizumab (anti-PD-1) in melanoma. N Engl J Med. 2013;369(2):134-44. https://doi.org/10.1056/NEJMoa1305133.

30. Yang JC, Hughes M, Kammula U, Royal R, Sherry RM, Topalian SL, et al. Ipilimumab (anti-CTLA4 antibody) causes regression of metastatic renal cell cancer associated with enteritis and hypophysitis. J Immunother. 2007;30(8): 825-30. https://doi.org/10.1097/CJl.0b013e318156e47e.

31. Nivolumab approved for liver cancer. Cancer Discov. 2017;7:OF3. https://doi. org/10.1158/2159-8290.CD-NB2017-138.

32. FDA. FDA grants accelerated approval to pembrolizumab for hepatocellular carcinoma: The U.S. Food and Drug Administration; 2018. https://www.fda. gov/drugs/fda-grants-accelerated-approval-pembrolizumab-hepatocellularcarcinoma. Accessed 14 Dec 2018.

33. Wilhelm SM, Carter C, Tang L, et al. BAY 43-9006 exhibits broad spectrum oral antitumor activity and targets the RAF/MEK/ERK pathway and receptor tyrosine kinases involved in tumor progression and angiogenesis. Cancer Res. 2004;64(19):7099-109. https://doi.org/10.1158/0008-5472.CAN-04-1443.

34. Qin S, Li A, Yi M, Yu S, Zhang M, Wu K. Recent advances on antiangiogenesis receptor tyrosine kinase inhibitors in cancer therapy. J Hematol Oncol. 2019;12(1):27. https://doi.org/10.1186/s13045-019-0718-5.

35. Dawkins J, Webster RM. The hepatocellular carcinoma market. Nat Rev Drug Discov. 2019:18(1):13-4. https://doi.org/10.1038/nrd.2018.146.

36. Cheng AL, Kang YK, Chen Z, Tsao CJ, Qin S, Kim JS, et al. Efficacy and safety of sorafenib in patients in the Asia-Pacific region with advanced hepatocellular carcinoma: a phase III randomised, double-blind, placebocontrolled trial. Lancet Oncol. 2009;10(1):25-34. https://doi.org/10.1016/S14 70-2045(08)70285-7.

37. Llovet JM, Villanueva A, Lachenmayer A, Finn RS. Advances in targeted therapies for hepatocellular carcinoma in the genomic era. Nat Rev Clin Oncol. 2015;12(7):408-24. https://doi.org/10.1038/ nrclinonc.2015.103.

38. Llovet JM, Pena CEA, Lathia CD, et al. Plasma biomarkers as predictors of outcome in patients with advanced hepatocellular carcinoma. Clin Cancer Res. 2012;18(8):2290-300. https://doi.org/10.1158/1078-0432.CCR-11-2175.

39. Raoul JL, Kudo M, Finn RS, Edeline J, Reig M, Galle PR. Systemic therapy for intermediate and advanced hepatocellular carcinoma: Sorafenib and beyond. Cancer Treat Rev. 2018;68:16-24. https://doi.org/10.1016/j.ctrv.2018.05.006.

40. Ren Z, Zhu K, Kang H, Lu MQ, Qu ZQ, Lu LG, et al. Randomized controlled trial of the prophylactic effect of urea-based cream on sorafenib-associated hand-foot skin reactions in patients with advanced hepatocellular carcinoma. J Clin Oncol. 2015;33(8):894-900. https://doi.org/10.1200/JCO.2 013.52 .9651

41. Abdel-Rahman O, Lamarca A. Development of sorafenib-related side effects in patients diagnosed with advanced hepatocellular carcinoma treated with sorafenib: a systematic-review and meta-analysis of the impact on survival. Expert Rev Gastroenterol Hepatol. 2017;11(1):75-83. https://doi.org/10.1 080/17474124.2017.1264874.

42. Branco F, Alencar RS, Volt F, et al. The impact of early dermatologic events in the survival of patients with hepatocellular carcinoma treated with Sorafenib. Ann Hepatol. 2017;16(2):263-8. https://doi.org/10.5604/16652 681.1231587.
43. Bruix J, Cheng AL, Meinhardt G, Nakajima K, de Sanctis Y, Llovet J. Prognostic factors and predictors of sorafenib benefit in patients with hepatocellular carcinoma: analysis of two phase III studies. J Hepatol. 2017; 67(5):999-1008. https://doi.org/10.1016/j.jhep.2017.06.026.

44. Ikeda M, Morizane C, Ueno M, Okusaka T, Ishii H, Furuse J. Chemotherapy for hepatocellular carcinoma: current status and future perspectives. Jpn J Clin Oncol. 2018;48(2):103-14. https://doi.org/10.1093/jjco/hyx180.

45. Greten TF, Lai CW, Li G, Staveley-O'Carroll KF. Targeted and immune-based therapies for hepatocellular carcinoma. Gastroenterology. 2019;156(2):51024. https://doi.org/10.1053/j.gastro.2018.09.051.

46. FDA. FDA approves atezolizumab plus bevacizumab for unresectable hepatocellular carcinoma: The U.S. Food and Drug Administration; 2020. https://www.fda.gov/drugs/drug-approvals-and-databases/fda-approves-a tezolizumab-plus-bevacizumab-unresectable-hepatocellular-carcinoma. Accessed 1 June 2020

47. Wilhelm SM, Dumas J, Adnane L, Lynch M, Carter CA, Schütz G, et al. Regorafenib (BAY 73-4506): a new oral multikinase inhibitor of angiogenic, stromal and oncogenic receptor tyrosine kinases with potent preclinical antitumor activity. Int J Cancer. 2011;129(1):245-55. https://doi.org/10.1002/ ijc.25864.

48. Villanueva A. Hepatocellular carcinoma. N Engl J Med. 2019;380(15):1450-62. https://doi.org/10.1056/NEJMra1713263

49. Xiang Q, Chen W, Ren M, Wang J, Zhang H, Deng DYB, et al. Cabozantinib suppresses tumor growth and metastasis in hepatocellular carcinoma by a dual blockade of VEGFR2 and MET. Clin Cancer Res. 2014;20(11):2959-70. https://doi.org/10.1158/1078-0432.CCR-13-2620.

50. Rimassa L, Abbadessa G, Personeni N, Porta C, Borbath I, Daniele B, et al. Tumor and circulating biomarkers in patients with second-line hepatocellular carcinoma from the randomized phase II study with tivantinib. Oncotarget. 2016;7(45):72622-33. https://doi.org/10.18632/oncota rget.11621.

51. Rimassa L, Assenat E, Peck-Radosavljevic M, Pracht M, Zagonel V, Mathurin $P$, et al. Tivantinib for second-line treatment of MET-high, advanced hepatocellular carcinoma (METIV-HCC): a final analysis of a phase 3, randomised, placebo-controlled study. Lancet Oncol. 2018;19(5):682-93. https://doi.org/10.1016/S1470-2045(18)30146-3.

52. Rimassa L, Kelley RK, Meyer T, Ryoo BY, Merle P, Park JW, et al. Outcomes based on plasma biomarkers for the phase III CELESTIAL trial of cabozantinib (C) versus placebo $(\mathrm{P})$ in advanced hepatocellular carcinoma (aHCC). Ann Oncol. 2019;30:v257-8. https://doi.org/10.1093/annonc/mdz247.006.

53. Zhu AX, Park JO, Ryoo BY, Yen CJ, Poon R, Pastorelli D, et al. Ramucirumab versus placebo as second-line treatment in patients with advanced hepatocellular carcinoma following first-line therapy with sorafenib (REACH): a randomised, double-blind, multicentre, phase 3 trial. Lancet Oncol. 2015; 16(7):859-70. https://doi.org/10.1016/S1470-2045(15)00050-9.

54. Kudo M. Ramucirumab as second-line systemic therapy in hepatocellular carcinoma. Liver Cancer. 2018;7(4):305-11. https:/doi.org/10.1159/000492534.

55. Ishida Y, Agata Y, Shibahara K, Honjo T. Induced expression of PD-1, a novel member of the immunoglobulin gene superfamily, upon programmed cell death. EMBO J. 1992;11(11):3887-95. https://doi.org/10.1002/j.1460-2075.1 992.tb05481.x

56. Freeman GJ, Long AJ, Iwai Y, Bourque K, Chernova T, Nishimura H, et al. Engagement of the PD-1 immunoinhibitory receptor by a novel B7 family member leads to negative regulation of lymphocyte activation. J Exp Med. 2000;192(7):1027-34. https://doi.org/10.1084/jem.192.7.1027.

57. Yau T, Park JW, Finn RS, et al. CheckMate 459: a randomized, multi-center phase III study of nivolumab (NIVO) vs sorafenib (SOR) as first-line (1L) treatment in patients (pts) with advanced hepatocellular carcinoma (aHCC). Ann Oncol. 2019;30:874.

58. Finn RS, Ryoo B-Y, Merle P, Kudo M, Bouattour M, Lim HY, et al. Pembrolizumab as second-line therapy in patients with advanced hepatocellular carcinoma in KEYNOTE-240: a randomized, double-blind, phase III trial. J Clin Oncol. 2020;38(3):193-202. https://doi.org/10.1200/JCO.19.01307.

59. Yau T. Nivolumab (NIVO) + ipilimumab (IPI) + cabozantinib (CABO) combination therapy in patients (pts) with advanced hepatocellular carcinoma (aHCC): results from CheckMate 040 [abstract]. In: Gastrointestinal Cancers Symposium: ASCO; 2020. https://meetinglibrary.asco.org/record/181 909/abstract. Accessed 24 Jan 2020

60. Allen E, Jabouille A, Rivera LB, et al. Combined antiangiogenic and anti-PDL1 therapy stimulates tumor immunity through HEV formation. Sci Transl Med. 2017;9:eaak9679. 
61. Khan KA, Kerbel RS. Improving immunotherapy outcomes with antiangiogenic treatments and vice versa. Nat Rev Clin Oncol. 2018;15(5):31024. https://doi.org/10.1038/nrclinonc.2018.9.

62. Yi M, Jiao D, Qin S, Chu Q, Wu K, Li A. Synergistic effect of immune checkpoint blockade and anti-angiogenesis in cancer treatment. Mol Cancer. 2019;18(1):60. https://doi.org/10.1186/s12943-019-0974-6.

63. Zhu XD, Sun HC. Emerging agents and regimens for hepatocellular carcinoma. J Hematol Oncol. 2019;12(1):110. https://doi.org/10.1186/s13045019-0794-6.

64. Kimura T, Kato Y, Ozawa Y, Kodama K, Ito J, Ichikawa K, et al. Immunomodulatory activity of lenvatinib contributes to antitumor activity in the Hepa1-6 hepatocellular carcinoma model. Cancer Sci. 2018;109(12): 3993-4002. https://doi.org/10.1111/cas.13806.

65. Xu J, Zhang Y, Jia R, Yue C, Chang L, Liu R, et al. Anti-PD-1 antibody SHR1210 combined with Apatinib for advanced hepatocellular carcinoma, gastric, or Esophagogastric junction Cancer: an open-label, dose escalation and expansion study. Clin Cancer Res. 2019;25(2):515-23. https://doi.org/1 0.1158/1078-0432.CCR-18-2484.

66. Wu K, Yi M, Qin S, Chu Q, Zheng X, Wu K. The efficacy and safety of combination of PD-1 and CTLA-4 inhibitors: a meta-analysis. Exp Hematol Oncol. 2019;8(1):26. https://doi.org/10.1186/s40164-019-0150-0.

67. Kelley RK. Efficacy, tolerability, and biologic activity of a novel regimen of tremelimumab (T) in combination with durvalumab (D) for patients (pts) with advanced hepatocellular carcinoma (aHCC) [abstract]. In: ASCO Virtual Scientific Program; 2020. https://meetinglibrary.asco.org/ record/185471/abstract.

68. Zhao H, Guo Y, Li S, et al. A novel anti-cancer agent Icaritin suppresses hepatocellular carcinoma initiation and malignant growth through the IL-6/ Jak2/Stat3 pathway. Oncotarget. 2015;6(31):31927-43. https://doi.org/10.1 8632/oncotarget.5578

69. Qin SK, Li Q, Ming Xu J, Liang J, Cheng Y, Fan Y, et al. Icaritin-induced immunomodulatory efficacy in advanced hepatitis B virus-related hepatocellular carcinoma: Immunodynamic biomarkers and overall survival. Cancer Sci. 2020;111(11):4218-31. https://doi.org/10.1111/cas.14641.

70. Mo D, Zhu H, Wang J, Hao H, Guo Y, Wang J, et al. Icaritin inhibits PD-L1 expression by targeting protein IkappaB kinase alpha. Eur J Immunol. 2021; 51(4):978-88. https://doi.org/10.1002/eji.202048905.

71. Fan Y, Li S, Ding X, Yue J, Jiang J, Zhao H, et al. First-in-class immunemodulating small molecule Icaritin in advanced hepatocellular carcinoma: preliminary results of safety, durable survival and immune biomarkers. BMC Cancer. 2019;19(1):279. https://doi.org/10.1186/s12885-019-5471-1.

72. Ho HK, Pok S, Streit S, Ruhe JE, Hart S, Lim KS, et al. Fibroblast growth factor receptor 4 regulates proliferation, anti-apoptosis and alpha-fetoprotein secretion during hepatocellular carcinoma progression and represents a potential target for therapeutic intervention. J Hepatol. 2009;50(1):118-27. https://doi.org/10.1016/j.jhep.2008.08.015.

73. Miura S, Mitsuhashi N, Shimizu H, Kimura F, Yoshidome H, Otsuka M, et al. Fibroblast growth factor 19 expression correlates with tumor progression and poorer prognosis of hepatocellular carcinoma. BMC Cancer. 2012;12(1): 56. https://doi.org/10.1186/1471-2407-12-56.

74. Hagel M, Miduturu C, Sheets M, Rubin N, Weng W, Stransky N, et al, First selective small molecule inhibitor of FGFR4 for the treatment of hepatocellular carcinomas with an activated FGFR4 signaling pathway. Cancer Discov. 2015;5(4):424-37. https://doi.org/10.1158/2159-8290. CD-14-1029

75. Lu X, Chen H, Patterson AV, Smaill JB, Ding K. Fibroblast growth factor receptor 4 (FGFR4) selective inhibitors as hepatocellular carcinoma therapy: advances and prospects. J Med Chem. 2019;62(6):2905-15. https://doi.org/1 0.1021/acs.jmedchem.8b01531.

76. Kim R, Sarker D, Macarulla T, Yau T, Choo SP, Meyer T, et al. 3650 - phase 1 safety and clinical activity of BLU-554 in advanced hepatocellular carcinoma (HCC). Ann Oncol. 2017;28:v122. https://doi.org/10.1093/annonc/mdx367.

77. Joshi JJ, Coffey H, Corcoran E, Tsai J, Huang CL, Ichikawa K, et al. H3B-6527 is a potent and selective inhibitor of FGFR4 in FGF19-driven hepatocellular carcinoma. Cancer Res. 2017;77(24):6999-7013. https://doi.org/10.1158/00085472.CAN-17-1865.

78. LoRusso PM. Inhibition of the PI3K/AKT/mTOR pathway in solid tumors. J Clin Oncol. 2016:34(31):3803-15. https://doi.org/10.1200/JCO.2014.59.0018.

79. Hua H, Kong Q, Zhang H, Wang J, Luo T, Jiang Y. Targeting mTOR for cancer therapy. J Hematol Oncol. 2019;12(1):71. https://doi.org/10.1186/s13 045-019-0754-1.
80. Garlich JR, De P, Dey N, et al. A vascular targeted pan phosphoinositide 3kinase inhibitor prodrug, SF1126, with antitumor and antiangiogenic activity. Cancer Res. 2008;68(1):206-15. https://doi.org/10.1158/0008-5472.CA $\mathrm{N}-07-0669$.

81. Singh AR, Joshi S, Burgoyne AM, Sicklick JK, Ikeda S, Kono Y, et al. Single agent and synergistic activity of the "first-in-class" dual PI3K/BRD4 inhibitor SF1126 with Sorafenib in hepatocellular carcinoma. Mol Cancer Ther. 2016; 15(11):2553-62. https://doi.org/10.1158/1535-7163.MCT-15-0976.

82. Mahadevan D, Chiorean EG, Harris WB, von Hoff DD, Stejskal-Barnett A, Qi $W$, et al. Phase I pharmacokinetic and pharmacodynamic study of the panPI3K/mTORC vascular targeted pro-drug SF1126 in patients with advanced solid tumours and B-cell malignancies. Eur J Cancer. 2012;48(18):3319-27. https://doi.org/10.1016/j.ejca.2012.06.027.

83. Sai J, Owens P, Novitskiy SV, Hawkins OE, Vilgelm AE, Yang J, et al. PI3K inhibition reduces mammary tumor growth and facilitates antitumor immunity and anti-PD1 responses. Clin Cancer Res. 2017;23(13):3371-84. https://doi.org/10.1158/1078-0432.CCR-16-2142.

84. Peng W, Chen JQ, Liu C, Malu S, Creasy C, Tetzlaff MT, et al. Loss of PTEN promotes resistance to $T$ cell-mediated immunotherapy. Cancer Discov. 2016;6(2):202-16. https://doi.org/10.1158/2159-8290.CD-15-0283.

85. Zhu AX, Kudo M, Assenat E, Cattan S, Kang YK, Lim HY, et al. Effect of everolimus on survival in advanced hepatocellular carcinoma after failure of sorafenib: the EVOLVE-1 randomized clinical trial. JAMA. 2014;312(1):57-67. https://doi.org/10.1001/jama.2014.7189.

86. Zhang SS, Song XH, Cao D, Xu Z, Fan B, Che L, et al. Pan-mTOR inhibitor MLN0128 is effective against intrahepatic cholangiocarcinoma in mice. J Hepatol. 2017;67(6):1194-203. https://doi.org/10.1016/j.jhep.2017.07.006.

87. Li H, Li X, Liu S, Guo L, Zhang B, Zhang J, et al. Programmed cell death-1 (PD-1) checkpoint blockade in combination with a mammalian target of rapamycin inhibitor restrains hepatocellular carcinoma growth induced by hepatoma cell-intrinsic PD-1. Hepatology. 2017;66(6):1920-33. https://doi. org/10.1002/hep.29360.

88. Pickup M, Novitskiy S, Moses HL. The roles of TGFbeta in the tumour microenvironment. Nat Rev Cancer. 2013;13(11):788-99. https://doi.org/10.1 038/nrc3603.

89. Yi M, Zhang J, Li A, Niu M, Yan Y, Jiao Y, et al. The construction, expression, and enhanced anti-tumor activity of YM101: a bispecific antibody simultaneously targeting TGF-beta and PD-L1. J Hematol Oncol. 2021;14(1): 27. https://doi.org/10.1186/s13045-021-01045-x.

90. Ungerleider N, Han C, Zhang J, Yao L, Wu T. TGFbeta signaling confers sorafenib resistance via induction of multiple RTKs in hepatocellular carcinoma cells. Mol Carcinog. 2017;56(4):1302-11. https://doi.org/10.1002/mc.22592.

91. Serova M, Tijeras-Raballand A, Dos Santos C, et al. Effects of TGF-beta signalling inhibition with galunisertib (LY2157299) in hepatocellular carcinoma models and in ex vivo whole tumor tissue samples from patients. Oncotarget. 2015;6(25):21614-27. https://doi.org/10.18632/oncota rget.4308.

92. Faivre S, Santoro A, Kelley RK, Gane E, Costentin CE, Gueorguieva I, et al. Novel transforming growth factor beta receptor I kinase inhibitor galunisertib (LY2157299) in advanced hepatocellular carcinoma. Liver Int. 2019;39(8):1468-77. https://doi.org/10.1111/liv.14113.

93. Kelley RK, Gane E, Assenat E, Siebler J, Galle PR, Merle P, et al. A phase 2 study of Galunisertib (TGF-beta1 receptor type I inhibitor) and Sorafenib in patients with advanced hepatocellular carcinoma. Clin Transl Gastroenterol. 2019;10(7):e00056. https://doi.org/10.14309/ctg. 0000000000000056.

94. Holmgaard RB, Schaer DA, Li Y, Castaneda SP, Murphy MY, Xu X, et al. Targeting the TGFbeta pathway with galunisertib, a TGFbetaRI small molecule inhibitor, promotes anti-tumor immunity leading to durable, complete responses, as monotherapy and in combination with checkpoint blockade. J Immunother Cancer. 2018;6(1):47. https://doi.org/10.1186/s4042 5-018-0356-4.

95. Bertrand A, Kostine M, Barnetche T, Truchetet ME, Schaeverbeke T. Immune related adverse events associated with anti-CTLA-4 antibodies: systematic review and meta-analysis. BMC Med. 2015;13(1):211. https://doi.org/10.1186/ s12916-015-0455-8.

96. Yu S, Li A, Liu Q, Yuan X, Xu H, Jiao D, et al. Recent advances of bispecific antibodies in solid tumors. J Hematol Oncol. 2017;10(1):155. https://doi. org/10.1186/s13045-017-0522-z

97. Ben Markman, Ben Tran, Hui Gan et al. O30 A Phase 1 study of AK104, a tetrameric bispecific antibody that targets PD-1 and CTLA-4 in patients with 
advanced solid tumors [abstract]. In: 34th Annual Meeting \& Pre-Conference Programs of the Society for Immunotherapy of Cancer (SITC 2019); 2019. 7. http://dx.doi.org/10.1186/s40425-019-0764-0. Accessed 10 Nov 2019.

98. Ji J. AK104, a PD-1/CTLA-4 bispecific antibody in combination with chemotherapy as first-line therapy in a phase $\mathrm{lb}$ trial in patients (pts) with advanced gastric (G) or gastroesophageal junction (GEJ) cancer [abstract]. In: Proceedings of the 111th Annual Meeting of the American Association for Cancer Research; 2020 June 22-24. Philadelphia: AACR; 2020. Abstract CT120. https://www.abstractsonline. com/pp8/\#!/9045/presentation/10619.

99. Dovedi SJ, Elder MJ, Yang C, Sitnikova SI, Irving L, Hansen A, et al. Design and efficacy of a monovalent Bispecific PD-1/CTLA4 antibody that enhances CTLA4 blockade on PD-1(+) activated T cells. Cancer Discov. 2021. https:// doi.org/10.1158/2159-8290.CD-20-1445.

100. Du K, Li Y, Liu J, et al. A bispecific antibody targeting GPC3 and CD47 induced enhanced antitumor efficacy against dual antigen-expressing HCC. Mol Ther. 2021;29(4):1572-84. https://doi.org/10.1016/j.ymthe.2021.01.006.

101. June $\mathrm{CH}, \mathrm{O}^{\prime}$ Connor RS, Kawalekar OU, et al. CAR T cell immunotherapy for human cancer. Science. 2018;359(6382):1361-5. https://doi.org/10.1126/ science.aar6711.

102. Yu S, Li A, Liu Q, Li T, Yuan X, Han X, et al. Chimeric antigen receptor T cells: a novel therapy for solid tumors. J Hematol Oncol. 2017;10(1):78. https://doi. org/10.1186/s13045-017-0444-9.

103. Zhou F, Shang W, Yu X, Tian J. Glypican-3: a promising biomarker for hepatocellular carcinoma diagnosis and treatment. Med Res Rev. 2018;38(2): 741-67. https://doi.org/10.1002/med.21455.

104. Gao H, Li K, Tu H, Pan X, Jiang H, Shi B, et al. Development of T cells redirected to glypican-3 for the treatment of hepatocellular carcinoma. Clin Cancer Res. 2014;20(24):6418-28. https://doi.org/10.1158/1078-0432. CCR-14-1170.

105. Guo X, Jiang H, Shi B, Zhou M, Zhang H, Shi Z, et al. Disruption of PD-1 enhanced the anti-tumor activity of chimeric antigen receptor $T$ cells against hepatocellular carcinoma. Front Pharmacol. 2018;9:1118. https://doi. org/10.3389/fphar.2018.01118.

106. Rafiq S, Yeku OO, Jackson HJ, Purdon TJ, van Leeuwen DG, Drakes DJ, et al. Targeted delivery of a PD-1-blocking scFv by CAR-T cells enhances antitumor efficacy in vivo. Nat Biotechnol. 2018;36(9):847-56. https://doi.org/1 $0.1038 /$ nbt.4195

107. Park TS, Rosenberg SA, Morgan RA. Treating cancer with genetically engineered T cells. Trends Biotechnol. 2011;29(11):550-7. https://doi.org/10.1 016/j.tibtech.2011.04.009

108. Hinrichs CS. Molecular pathways: breaking the epithelial Cancer barrier for chimeric antigen receptor and T-cell receptor gene therapy. Clin Cancer Res. 2016;22(7):1559-64. https://doi.org/10.1158/1078-0432.CCR-15-1294.

109. Russell SJ, Peng KW, Bell JC. Oncolytic virotherapy. Nat Biotechnol. 2012; 30(7):658-70. https://doi.org/10.1038/nbt.2287.

110. Raja J, Ludwig JM, Gettinger SN, Schalper KA, Kim HS. Oncolytic virus immunotherapy: future prospects for oncology. J Immunother Cancer. 2018; 6(1):140. https://doi.org/10.1186/s40425-018-0458-z.

111. Heo J, Reid T, Ruo L, Breitbach CJ, Rose S, Bloomston M, et al. Randomized dose-finding clinical trial of oncolytic immunotherapeutic vaccinia JX-594 in liver cancer. Nat Med. 2013;19(3):329-36. https://doi org/10.1038/nm.3089.

112. Park B-H, Hwang T, Liu T-C, Sze DY, Kim JS, Kwon HC, et al. Use of a targeted oncolytic poxvirus, JX-594, in patients with refractory primary or metastatic liver cancer: a phase I trial. Lancet Oncol. 2008;9(6):533-42. https://doi.org/10.1016/S1470-2045(08)70107-4.

113. Qin W, Cao Z-Y, Xu X-D, et al. Recent advances regarding tumor microenvironment and immunotherapy in hepatocellular carcinoma. Hepatoma Res. 2020;6. https://doi.org/10.20517/2394-5079.2020.04.

114. Fukuhara $H$, Ino $Y$, Todo T. Oncolytic virus therapy: a new era of cancer treatment at dawn. Cancer Sci. 2016;107(10):1373-9. https://doi.org/10.1111/cas.13027.

115. Tomás-Loba A, Manieri E, González-Terán B, Mora A, Leiva-Vega L, Santamans AM, et al. p38y is essential for cell cycle progression and liver tumorigenesis. Nature. 2019;568(7753):557-60. https://doi.org/10.1038/s41 586-019-1112-8.

116. Haanen JB, Cerundolo V. NKG2A, a new kid on the immune checkpoint block. Cell. 2018;175(7):1720-2. https://doi.org/10.1016/j.cell.2018.11.048.

117. van Montfoort N, Borst L, Korrer MJ, Sluijter M, Marijt KA, Santegoets SJ, et al. NKG2A blockade potentiates CD8 T cell immunity induced by Cancer vaccines. Cell. 2018;175(7):1744-55 e1715. https://doi.org/10.1016/j.cell.2018.10.028.
118. André $P$, Denis C, Soulas C, et al. Anti-NKG2A mAb Is a Checkpoint Inhibitor that Promotes Anti-tumor Immunity by Unleashing Both T and NK Cells. Cell. 2018;175:1731-1743.e1713.

119. Dougall WC, Kurtulus S, Smyth MJ, Anderson AC. TIGIT and CD96: new checkpoint receptor targets for cancer immunotherapy. Immunol Rev. 2017; 276(1):112-20. https://doi.org/10.1111/imr.12518.

120. Schooten E, Di Maggio A, Henegouwen PMPVE, Kijanka MM. MAGE-A antigens as targets for cancer immunotherapy. Cancer Treat Rev. 2018;67: 54-62. https://doi.org/10.1016/j.ctrv.2018.04.009.

121. Liu X, Bao X, Hu M, Chang H, Jiao M, Cheng J, et al. Inhibition of PCSK9 potentiates immune checkpoint therapy for cancer. Nature. 2020;588(7839): 693-8. https://doi.org/10.1038/s41586-020-2911-7.

122. Yuan J, Cai T, Zheng X, Ren Y, Qi J, Lu X, et al. Potentiating CD8(+) T cell antitumor activity by inhibiting PCSK9 to promote LDLR-mediated TCR recycling and signaling. Protein Cell. 2021;12(4):240-60. https://doi.org/10.1 007/s13238-021-00821-2

123. Zheng R, Qu C, Zhang S, Zeng H, Sun K, Gu X, et al. Liver cancer incidence and mortality in China: temporal trends and projections to 2030. Chin J Cancer Res. 2018;30(6):571-9. https://doi.org/10.21147/j. issn.1000-9604.2018.06.01.

124. Chen W, Zheng R, Baade PD, Zhang S, Zeng H, Bray F, et al. Cancer statistics in China, 2015. CA Cancer J Clin. 2016;66(2):115-32. https://doi.org/10.3322/ caac. 21338 .

125. Keam SJ. Toripalimab: First Global Approval. Drugs. 2019;79(5):573-8. https:// doi.org/10.1007/s40265-019-01076-2.

126. Chi ZH, Tang BX, Sheng XN, Si L, Cui C, Kong Y, et al. A phase II study of JS001, a humanized PD-1 mAb, in patients with advanced melanoma in China. J Clin Oncol. 2018;36(15_suppl):9539. https://doi.org/10.1200/JCO.201 8.36.15_suppl.9539.

127. Xu RH, Wang FH, Li Q, Shi J, Shen L, Zhang Q, et al. Recombinant humanised anti-PD-1 monoclonal antibody (JS001) treatment for patients with refractory or metastatic nasopharyngeal carcinoma: preliminary results of an open-label, phase 1b/2, clinical study. Lancet Oncol. 2017;18:S1. https://doi.org/10.1016/S1470-2045(17)30757-X.

128. Sheng XN, Chi ZH, Cui CL, Si L, Tang B, Yan X, et al. Preliminary results from patients with metastatic urothelial carcinoma (UC) in a phase 2 study of JS001, an anti-PD-1 monoclonal antibody. J Clin Oncol. 2018;36(15_suppl): e16505. https://doi.org/10.1200/JCO.2018.36.15_suppl.e16505.

129. Zhang T, Song X, Xu L, Ma J, Zhang Y, Gong W, et al. The binding of an anti-PD-1 antibody to FcgammaRlota has a profound impact on its biological functions. Cancer Immunol Immunother. 2018;67(7):1079-90. https://doi.org/10.1007/s00262-018-2160-x.

130. Qin S, Ren Z, Meng Z, Chen Z, Chai X, Xiong J, et al. Camrelizumab in patients with previously treated advanced hepatocellular carcinoma: a multicentre, open-label, parallel-group, randomised, phase 2 trial. Lancet Oncol. 2020;21(4):571-80. https://doi.org/10.1016/ S1470-2045(20)30011-5.

131. TingTing $P$, XiaoNan $C$. Research advances in drug therapy for advanced primary liver cancer. J Clin Hepatol. 2020;36:194-7 (in Chinese).

132. Lam W, Jiang Z, Guan F, et al. PHY906(KD018), an adjuvant based on a 1800-year-old Chinese medicine, enhanced the anti-tumor activity of Sorafenib by changing the tumor microenvironment. Sci Rep. 2015;5(1): 9384. https://doi.org/10.1038/srep09384.

133. Changou CA, Shiah HS, Chen LT, Liu S, Luh F, Liu SH, et al. A phase II clinical trial on the combination therapy of PHY906 plus Capecitabine in hepatocellular carcinoma. Oncologist. 2021;26(3):e367-73. https://doi.org/10.1002/onco.13582.

134. Yen $Y$, So S, Rose M, Saif MW, Chu E, Liu SH, et al. Phase I/II study of PHY906/capecitabine in advanced hepatocellular carcinoma. Anticancer Res. 2009;29(10):4083-92.

135. Chen F, Zhang J, He Y, et al. Glycyrrhetinic acid-decorated and reductionsensitive micelles to enhance the bioavailability and anti-hepatocellular carcinoma efficacy of tanshinone IIA. Biomater Sci. 2016;4(1):167-82. https:// doi.org/10.1039/C5BM00224A.

136. Tang JL. Research priorities in traditional Chinese medicine. BMJ. 2006; 333(7564):391-4. https://doi.org/10.1136/bmj.333.7564.391.

137. Li X, Shao C, Shi Y, Han W. Lessons learned from the blockade of immune checkpoints in cancer immunotherapy. J Hematol Oncol. 2018;11(1):31. https://doi.org/10.1186/s13045-018-0578-4.

138. Llovet JM, Hernandez-Gea V. Hepatocellular carcinoma: reasons for phase III failure and novel perspectives on trial design. Clin Cancer Res. 2014;20(8): 2072-9. https://doi.org/10.1158/1078-0432.CCR-13-0547. 
139. Sun $H$, Zhu MS, Wu WR, Shi XD, Xu LB. Role of anti-angiogenesis therapy in the management of hepatocellular carcinoma: the jury is still out. World J Hepatol. 2014;6(12):830-5. https://doi.org/10.4254/wjh.v6.i12.830.

140. Niu LL, Liu LP, Yang SL, et al. New insights into sorafenib resistance in hepatocellular carcinoma: responsible mechanisms and promising strategies. Biochim Biophys Acta Rev Cancer. 2017:1868:564-70.

141. Joyce JA, Fearon DT. T cell exclusion, immune privilege, and the tumor microenvironment. Science. 2015;348(6230):74-80. https://doi.org/10.1126/ science.aaa6204.

142. Hanahan D, Coussens LM. Accessories to the crime: functions of cells recruited to the tumor microenvironment. Cancer Cell. 2012;21(3):309-22. https://doi.org/10.1016/j.ccr.2012.02.022.

143. Zhu AX, Stuart K, Blaszkowsky LS, Muzikansky A, Reitberg DP, Clark JW, et al. Phase 2 study of cetuximab in patients with advanced hepatocellular carcinoma. Cancer. 2007;110(3):581-9. https://doi.org/10.1002/cncr.22829.

144. Chen Y, Ramjiawan RR, Reiberger T, Ng MR, Hato T, Huang Y, et al. CXCR4 inhibition in tumor microenvironment facilitates anti-programmed death receptor-1 immunotherapy in sorafenib-treated hepatocellular carcinoma in mice. Hepatology. 2015;61(5):1591-602. https://doi.org/10.1002/hep.27665.

145. Zhu AX, Kang YK, Rosmorduc O, Evans TR, Santoro A, Ross P, et al. Biomarker analyses of clinical outcomes in patients with advanced hepatocellular carcinoma treated with Sorafenib with or without Erlotinib in the SEARCH trial. Clin Cancer Res. 2016;22(19):4870-9. https://doi.org/10.1158/1078-0432.CCR-15-2883.

146. Zhu AX, Rosmorduc O, Evans TR, et al. SEARCH: a phase III, randomized, double-blind, placebo-controlled trial of sorafenib plus erlotinib in patients with advanced hepatocellular carcinoma. J Clin Oncol. 2015;33(6):559-66. https://doi.org/10.1200/JCO.2013.53.7746.

147. Tang XQ. Tumor-associated macrophages as potential diagnostic and prognostic biomarkers in breast cancer. Cancer Lett. 2013;332(1):3-10. https://doi.org/10.1016/j.canlet.2013.01.024.

148. Nishino M, Ramaiya NH, Hatabu H, Hodi FS. Monitoring immune-checkpoint blockade: response evaluation and biomarker development. Nat Rev Clin Oncol. 2017;14(11):655-68. https://doi.org/10.1038/nrclinonc.2017.88.

149. Yi M, Jiao D, Xu H, Liu Q, Zhao W, Han X, et al. Biomarkers for predicting efficacy of PD-1/PD-L1 inhibitors. Mol Cancer. 2018;17(1):129. https://doi. org/10.1186/s12943-018-0864-3.

150. Moslehi JJ, Salem JE, Sosman JA, Lebrun-Vignes B, Johnson DB. Increased reporting of fatal immune checkpoint inhibitor-associated myocarditis. Lancet. 2018;391(10124):933. https://doi.org/10.1016/S01406736(18)30533-6.

151. Heinzerling L, Ott PA, Hodi FS, et al. Cardiotoxicity associated with CTLA4 and PD1 blocking immunotherapy. J Immunotherapy Cancer. 2016;4(1):50. https://doi.org/10.1186/s40425-016-0152-y.

152. Johnson DB, Balko JM, Compton ML, et al. Fulminant myocarditis with combination immune checkpoint blockade. N Engl J Med. 2016;375(18): 1749-55. https://doi.org/10.1056/NEJMoa1609214.

153. Hinrichs CS, Restifo NP. Reassessing target antigens for adoptive T-cell therapy. Nat Biotechnol. 2013;31(11):999-1008. https://doi.org/10.1038/nbt.2725.

154. Di Stasi A, Tey SK, Dotti G, et al. Inducible apoptosis as a safety switch for adoptive cell therapy. N Engl J Med. 2011;365(18):1673-83. https://doi.org/1 0.1056/NEJMoa1106152.

155. Kloss CC, Condomines M, Cartellieri M, Bachmann M, Sadelain M. Combinatorial antigen recognition with balanced signaling promotes selective tumor eradication by engineered T cells. Nat Biotechnol. 2013; 31(1):71-5. https://doi.org/10.1038/nbt.2459.

156. Yu S, Yi M, Qin S, Wu K. Next generation chimeric antigen receptor T cells: safety strategies to overcome toxicity. Mol Cancer. 2019;18(1):125. https:// doi.org/10.1186/s12943-019-1057-4.

157. Angelbello AJ, Chen JL, Childs-Disney JL, Zhang P, Wang ZF, Disney MD. Using genome sequence to enable the Design of Medicines and Chemical Probes. Chem Rev. 2018;118(4):1599-663. https://doi.org/10.1021/acs.chemrev.7b00504.

158. Salk JJ, Schmitt MW, Loeb LA. Enhancing the accuracy of next-generation sequencing for detecting rare and subclonal mutations. Nat Rev Genet. 2018;19(5):269-85. https://doi.org/10.1038/nrg.2017.117.

159. Love-Koh J, Peel A, Rejon-Parrilla JC, Ennis K, Lovett R, Manca A, et al. The future of precision medicine: potential impacts for health technology assessment. Pharmacoeconomics. 2018;36(12):1439-51. https://doi.org/10.1 007/s40273-018-0686-6.

160. Tu Y. Artemisinin-a gift from traditional Chinese medicine to the world (Nobel lecture). Angew Chem Int Ed Eng. 2016;55(35):10210-26. https://doi. org/10.1002/anie.201601967.
161. Rebecca WW, Nicastri MC, Fennelly C, Chude Cl, Barber-Rotenberg JS, Ronghe A, et al. PPT1 promotes tumor growth and is the molecular target of Chloroquine derivatives in Cancer. Cancer Discov. 2019;9(2):220-9. https://doi.org/10.1158/2159-8290.CD-18-0706

\section{Publisher's Note}

Springer Nature remains neutral with regard to jurisdictional claims in published maps and institutional affiliations.

\section{Ready to submit your research? Choose BMC and benefit from:}

- fast, convenient online submission

- thorough peer review by experienced researchers in your field

- rapid publication on acceptance

- support for research data, including large and complex data types

- gold Open Access which fosters wider collaboration and increased citations

- maximum visibility for your research: over $100 \mathrm{M}$ website views per year

At BMC, research is always in progress.

Learn more biomedcentral.com/submissions 